\title{
PROBLEMS AND THEIR SOLUTIONS IN PRACTICAL APPLICATION OF EUROCODES IN SEISMIC DESIGN OF RC STRUCTURES
}

\section{PROBLEMI I NJIHOVA REŠENJA U PRAKTIČNOJ PRIMENI EVORKODOVA ZA PROJEKTOVANJE AB KONSTRUKCIJA}

Jordan MILEV

PREGLEDNI RAD

REVIEW PAPER

UDK: 624.9 .042 .7

699.841

doi: 10.5937/grmk1603003M

\section{INTRODUCTION}

The structural Eurocodes are implemented in Bulgaria for seismic design of new buildings. Moreover they are obligatory standard for design of important and significant residential and office buildings. This fact will increase margin of safety of those buildings for sure because Eurocodes are newer and more comprehensive system of structural design standards compared to old Bulgarian codes. However some problems appear in application of those new and advanced standards in Bulgarian design and construction practice.

Most of those problems are already discussed in many references (please see [1] $\div[6]$ ). The main goal of this report is to show how those problems are solved in the real application of structural Eurocodes. Special attention is paid to the problems which are developed in using Eurocode 8 in seismic design of reinforced concrete buildings.

\section{MAJOR STRUCTURAL PROBLEMS IN APPLICATION OF EUROCODES IN SEISMIC DESIGN OF RC STRUCTURES}

The major structural problems in application of Eurocode 8 could be roughly classified as follows:

- More comprehensive design checks, detailing rules, etc. which leads to some solutions which are not typical for the current design and construction practice;

- Requirements for application of some new technologies in execution of building structures such as

Jordan Milev, prof. PhD,

Department of Reinforced Concrete Structures,

University of Architecture, Civil Engineering and Geodesy,

Sofia, Bulgaria, j.milev@yoda-bg.com higher grade concrete, effective splicing of the reinforcement, advanced detailing which ensure stable seismic response of the whole structure, etc.;

- Higher requirements for architectural and functional solutions in order to avoid the unstable and unclear seismic response of structural system of the building i.e. penalties for irregularity in plan and in elevation as well as for the torsionally flexible systems, etc.

There are completely new requirements of Eurocode 8 in comparison it with the old Bulgarian seismic standard. They could be briefly listed as follows:

- New seismic zonation which is based on the current seismic hazard definitions is implemented;

- New limit state is implemented - damage limitation level (DLL);

- Three ductility classes are presented in Eurocode 8 - low, medium, and high - DCL, DCM and DCH;

- Stiffness reduction of structural elements of seismic structure is required;

- Some precise checks for regularity in plan and elevation as well as for torsionally flexible system are required;

- The concept with "primary" and "secondary" seismic elements is implemented;

- The new structural system with "large lightly reinforced walls" is introduced;

- Capacity correction of action effects from the analysis are required;

- Capacity design procedure is applied for seismic design. 
The seismic analysis of the RC structures according to Eurocode 8 is completely different compared with the old Bulgarian seismic code because of the required by Eurocode 8 capacity design procedure. This procedure requires comprehensive checks for ensuring the corresponding ductility, strength and stiffness of the structure.

The completely new checks for wall type of structures for Bulgarian design practice could be systemized as follows:

- Providing the local ductility by design of special confined boundary elements in the critical zone of the wall which in most of the cases leads to increase of the thickness of wall or application of local widening of the boundary area ("dumbbells") - both of the above solutions are not typical for Bulgarian constructions practice;

- The procedure for calculation of the length of confined boundary elements is too complicated and leads to too long confined boundary elements;

- Confined concrete application for detailing confined boundary elements in the critical zone;

- Different section design checks for shear especially for $\mathrm{DCH}$ where the design requirements for shear in compression strut are too high and they could hardly be fulfilled even for typical cases;

- Completely new checks are implemented i.e. sliding shear failure check at the wall base for $\mathrm{DCH}$;

- Vertical web reinforcement shall be taken into account in calculation of flexural resistance of wall sections;

- Composite wall sections consisting of connected or intersecting rectangular segments (L-, T-, U-, I- or similar sections) should be taken as integral units, consisting of a web or webs parallel or approximately parallel to the direction of the acting seismic shear force and a flange or flanges perpendicular or approximately perpendicular to it;

- The detailing rules are more complicated and different comparing with old Bulgarian seismic code;

The differences between old Bulgarian seismic code and Eurocode 8 for the case of frame structures are even more significant. Some new knowledge is required for the structural design engineers to apply Eurocode 8 in the real design practice. The most important new requirements for the seismic design of frame structures which are introduced by Eurocode 8 and are completely new for Bulgarian design practice could be classified as follows:

- Local ductility requirements by the design of suitable critical regions in both beams and columns. These critical regions are detailed by application of confined concrete;

- "Strong" columns - "Weak" beams design concept;

- High requirements for the shear design of beams and columns especially for $\mathrm{DCH}$;

- The detailing rules are much more complicated and difficult for fulfilling. Most problems appear with ensuring the maximum reinforcement ratio for the top beam reinforcement, the maximum diameter limitation of the bars which are bonded in the beam column joints as well as too small distance between stirrups along the splicing length of longitudinal bars in columns and walls;

- Completely new design checks are introduced, i.e. beam-column checks for $\mathrm{DCH}$.

Additionally there are some problems in Eurocode 8 which are not completely clarified, i.e. as follows:

- The procedure for recognition of torsionally flexible system is not presented but it is left to the National Annex;

- The problems with distinguishing primary and secondary elements are incompletely defined;

- It is not completely explained how to reduce the stiffness of members with plastic hinges for the purpose of linear analysis;

- The requirements for ductility checks of composite wall sections are given way too generally.

Moreover the price of structures is slightly increased in comparison with the current Bulgarian practice when the building is designed according to Eurocodes. However higher increase of the building price is expected due to more strict requirements of Eurocode 8 for regularity of the structure which leads to compromising with architectural and functional features of the building.

Particularly for Bulgaria there are some additional problems in application of Eurocode 8 as follows:

- The different theoretical background of Eurocode 8 and the old Bulgarian seismic code;

- Some of the paragraphs of the Bulgarian National Annex are too general and fail to solve the problem they should solve.

Some of the problems defined above are discussed in more details bellow and some proposals for the solutions of some of them are presented (please see [6] for more details).

\section{PROBLEMS AND SOLUTIONS IN GENERAL DESIGN OF RC BUILDINGS}

\subsection{Ductility levels}

Eurocode 8 gives the possibility for application of three levels of ductility - low (DCL), medium (DCM) and high $(\mathrm{DCH})$. The code does not recommend application of specific ductility level for different kind of structural types or for different level of seismicity. The only exception is the fact that DCL is not recommended (but it is not prohibited) for the areas with medium and high seismicity. In author's opinion DCL could be effectively applied for the small RC buildings, i.e. one or two--storey houses, etc. Definition of different ductility levels according to Eurocode 8 is given in Fig. 1 .

However the DCH is hardly applicable to seismic design of RC wall type of buildings. The main reason for that is reduction of the bearing resistance on compression strut $\left(\mathbf{V}_{\mathbf{R d} \text {,max }}\right)$ in the critical region by taking its value as $40 \%$ of the value outside the critical region. This strict requirement leads to the thickness of the wall in critical region which is too high for practical applications. Moreover the high thickness is usually combined with high grade of concrete in this case. 


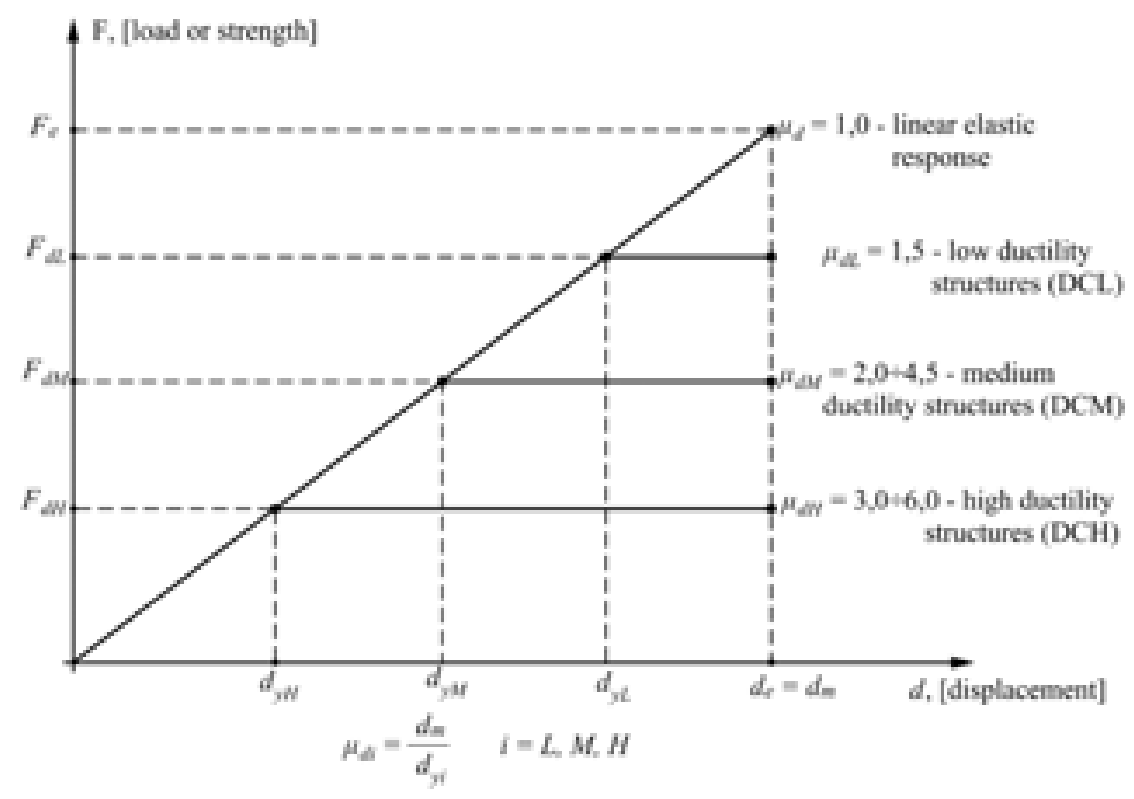

Fig. 1. Ductility levels Low, Medium and High (DCL, DCM and DCH)

\subsection{Stiffness correction for linear seismic analysis} of RC Structures

According to the requirements of Eurocode 8 the stiffness of the RC members for linear analysis should be reduced. However there are not detailed instructions how exactly to reduce that stiffness. It is proposed in [6] to apply the proposals of the Japanese AIJ Standard for
Structural Calculations of RC Structures (from 2010) in order to reduce the stiffness of the structural elements by plastic hinges. The author's proposal based on the above mentioned standard is given in Table 1 and in Figs $2 \div 3$.

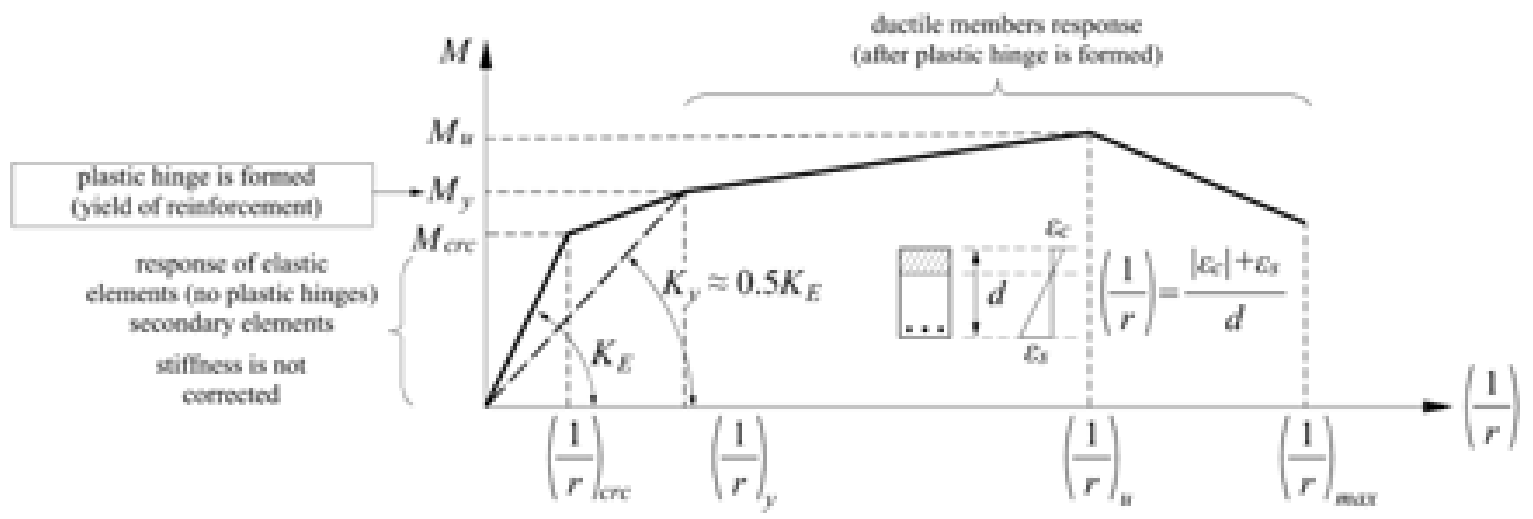

Fig. 2. Moment curvature relationship for RC section 


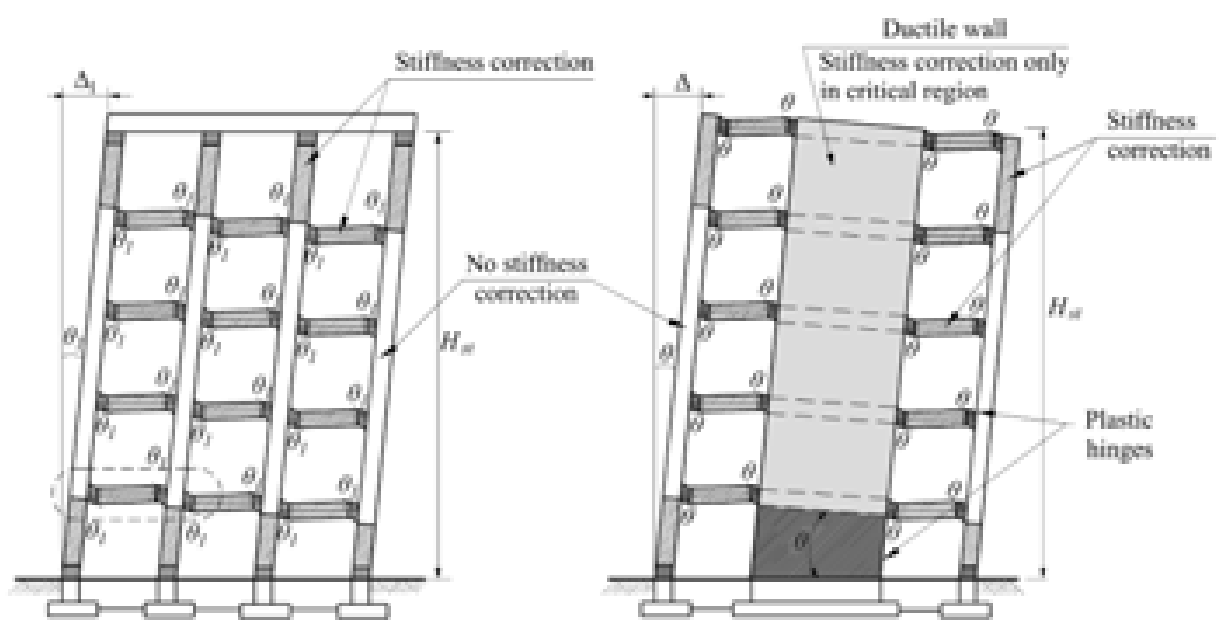

Fig. 3. Stiffness reduction for seismic members with plastic hinges according to Eurocode 8

Table 1. Proposed stiffness reduction for members with plastic hinges according to AIJ

\begin{tabular}{|c|c|c|c|c|}
\hline \multicolumn{2}{|c|}{ Member } & \multirow{2}{*}{$\begin{array}{c}\text { Bending } \\
\text { stiffness }\end{array}$} & \multirow{2}{*}{$\begin{array}{c}\text { Axial stiffness } \\
1.0(\text { or } \infty)\end{array}$} & \multirow{2}{*}{$\begin{array}{c}\text { Shear stiffness } \\
1.0(\text { or } \infty)\end{array}$} \\
\hline \multirow[t]{2}{*}{ Beams } & $\begin{array}{l}\text { without plastic } \\
\text { hinges }\end{array}$ & & & \\
\hline & with plastic hinges & $0.3 \div 0.5$ & 1.0 or $\infty$ & $0.3 \div 1.0($ or $\infty)$ \\
\hline \multirow{3}{*}{ Колони } & $\begin{array}{l}\text { without plastic } \\
\text { hinges }\end{array}$ & 1.0 & 1.0 & 1.0 (or $\infty)$ \\
\hline & $\begin{array}{c}\text { with one plastic } \\
\text { hinge }\end{array}$ & 0.7 & 1.0 & $1.0($ or $\infty)$ \\
\hline & $\begin{array}{c}\text { with two plastic } \\
\text { hinge }\end{array}$ & $0.3 \div 0.5$ & 1.0 & $1.0($ or $\infty)$ \\
\hline \multirow[b]{2}{*}{ Structural walls } & $\begin{array}{l}\text { without plastic } \\
\text { hinges }\end{array}$ & 1.0 & 1.0 & $0.5 \div 1.0$ \\
\hline & $\begin{array}{l}\text { with plastic hinge } \\
\text { (stiffnes reduction } \\
\text { applied for the } \\
\text { hinge region) }\end{array}$ & $0.3 \div 0.5$ & 1.0 & $0.3 \div 0.5$ \\
\hline \multicolumn{2}{|c|}{ Beam - column joint } & - & - & 1.0 \\
\hline \multicolumn{2}{|c|}{ Plate (floor structure) } & 0.0 & 1.0 or $\infty$ & 1.0 or $\infty$ \\
\hline
\end{tabular}

\subsection{Recognition of torsionally flexible systems}

A lot of attention is paid in Eurocode 8 for recognition and possibly avoiding torsionally flexible systems. The penalty for torsionally flexible system is behaviour factor reduction by about $50 \%$ for such systems compared to the wall structures and even much more compared to frame structures. However Eurocode 8 fails to provide clear procedure for recognition of torsionally flexible systems. This problem is left to the National Annexes. The procedure presented below is adopted from [5] and is presented in Fig. 4 . The torsionally flexible systems are extremely dangerous during earthquakes. A heavily damaged building with such system is presented in Fig 5.

It is highly recommended to avoid torsionally flexible systems in practical seismic design of RC structures. A practical example how to avoid torsionally flexible system is presented in Fig. 6 and Fig. 7. 


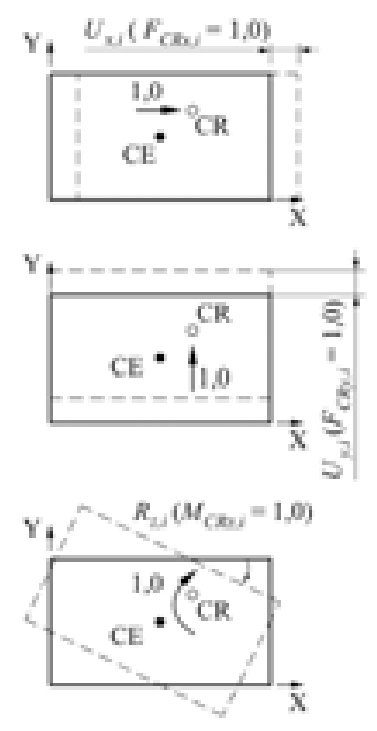

1. Three static load cases are defined for each $i$ storey $\left(F_{C R x, i}=1 ; F_{C R y, i}=1\right.$; $M_{C R z, i}=1$ ), with loads applied in the centre of rigidity CR;

2. The following displacements and rotations are calculated for each $i$ storey:

a. Displacement $U_{x, i}\left(F_{C R x, i}=1\right)$ at the centre of rigidity along the first principal direction of distribution of horizontal seismic action $X$ for load case $F_{C R x, i}=1$ (force, equal to 1 with direction $X$ and applied in the centre of rigidity CR at story $i$ );

b. Displacement $U_{y, i}\left(F_{C R y, i}=1\right)$ at the centre of rigidity along the second principal direction of distribution of horizontal seismic action $Y$ for load case $F_{C R y, i}=1$ (force, equal to 1 with direction $Y$ and applied in the centre of rigidity $\mathrm{CR}$ at story $i)$;

c. Rotation $R_{z, i}\left(M_{C R z, i}=1\right)$ at the centre of rigidity about vertical axis $Z$ for load case $M_{C R z, i}=1$ (moment. Equal to 1 and applied in the centre of rigidity $\mathrm{CR}$ at story $i$ );

3. Stiffnesses $K_{X, i}$ and $K_{Y, i}$ are calculated for each story $i$, as well as the torsional stiffness $K_{T, i}$ as follows:

$$
K_{X, i}=\frac{1}{U_{x, i}\left(F_{C R x, i}=1\right)} \quad K_{Y, i}=\frac{1}{U_{y, i}\left(F_{C R y, i}=1\right)} \quad K_{T, i}=\frac{1}{R_{z, i}\left(M_{C R z, i}=1\right)}
$$

4. Torsional radiuses $r_{x, i}$ and $r_{y, i}$ are calculated for each story as follows:

$$
r_{x, i}=\sqrt{\frac{K_{T, i}}{K_{Y, i}}} \quad r_{y, i}=\sqrt{\frac{K_{T, i}}{K_{X, i}}}
$$

5. The system fails to be torsionally flexible if the following is verified:

$$
r_{x, i} \geq l_{s, i} ; r_{y, i} \geq l_{s, i} \text {; }
$$

a. The radius of gyration of the floor mass in plan $I_{s, i}$ is calculated generally as follows:

$$
l_{s, i}=\sqrt{\frac{I_{m, i}}{m_{i}}}
$$

$I_{m, i}$ polar mass moment of inertia of floor mass $m_{i}$ about the centre of mass for story $i$;

$m_{i}$ floor mass for story $i$

Fig. 4. Recognition of torsionally flexible system

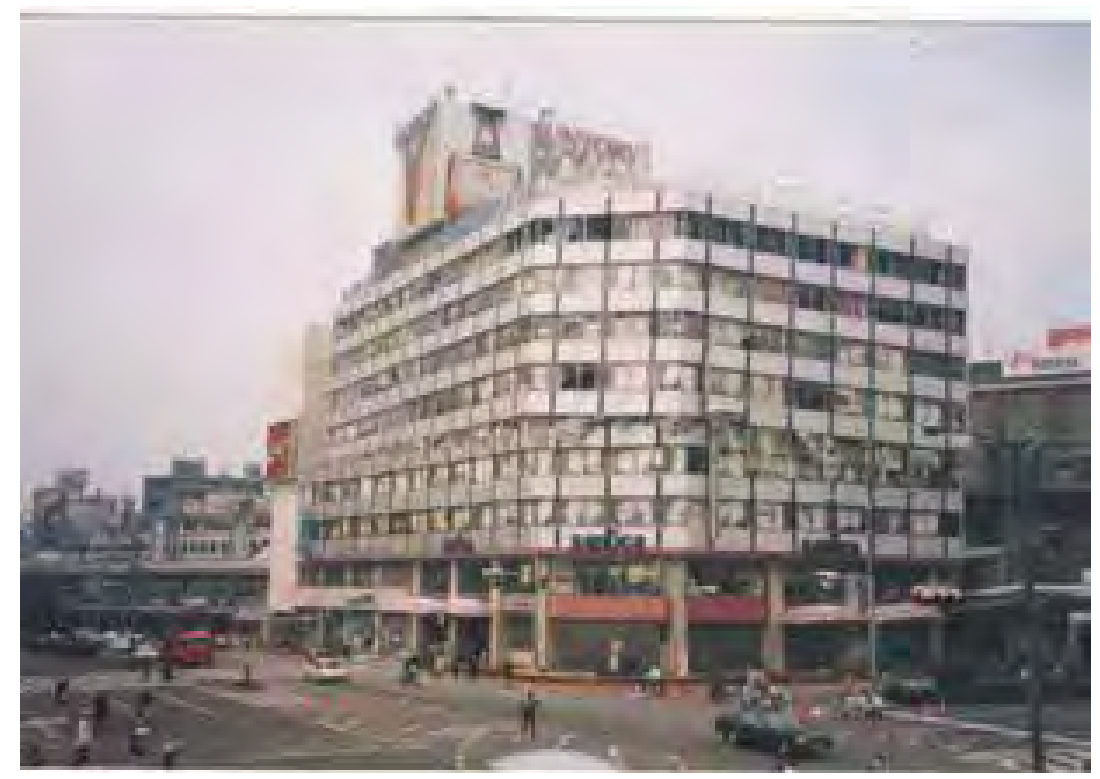

Fig. 5. Heavy damaged office building with torsionally flexible system during the earthquake in Kobe 1995 



Fig. 6. The example building as an example for avoiding torsionally flexible system

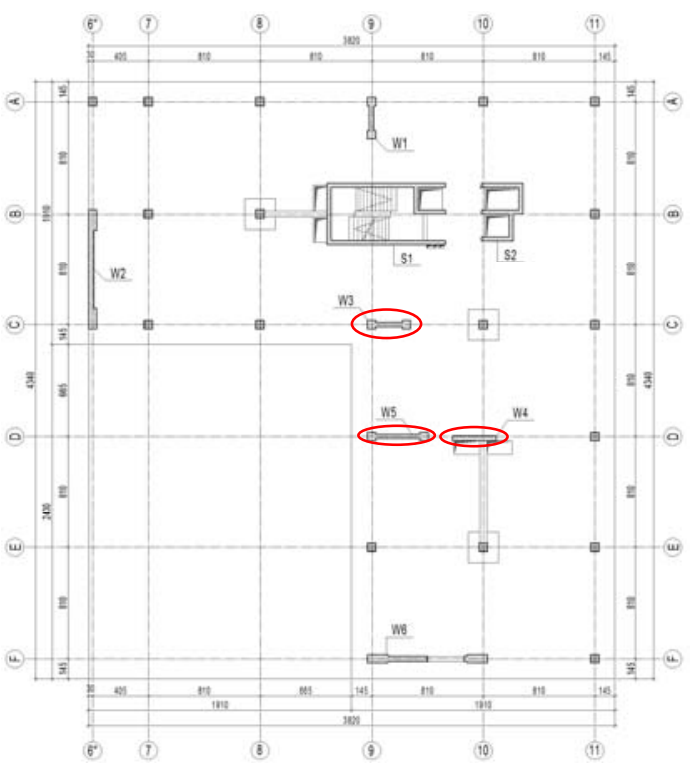

a)Torsionally flexible system

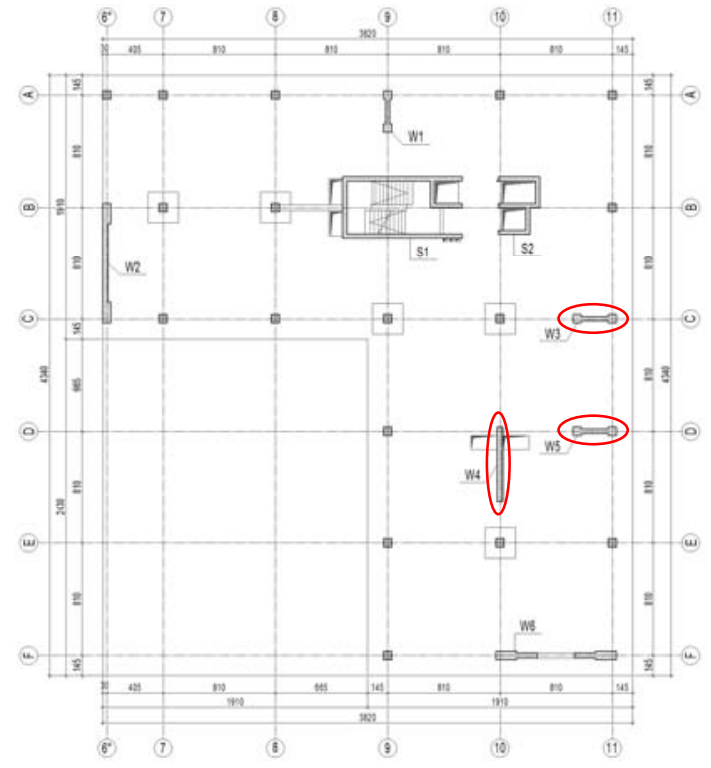

b) Wall system

Fig. 7. Avoiding torsionally flexible system in the example building

\subsection{Capacity correction of the analysis effects}

The analysis effects are capacity corrected according to Eurocode 8. A bending moment envelope diagram with consideration for the tension shift is adopted taking into account modelling uncertainties and post-elastic dynamic effects. Moreover, the possible effects of increase in shear forces due to post-yield behaviour. compared to those obtained from analysis, must be considered by implementation of shear force magnification factor. Its value is $\varepsilon=1.5$ for DCM, while for DCH exact calculations have to be done, taking into account overstrength, flexural capacity and structure response. In frame structures the shear failure mode is avoided by calculating design shear forces based on plastic hinge mechanism for the given member, thus allowing the element to resist the maximal shear force that can be developed before forming the mechanism. Walls correction is presented in Fig $8 \div 9$ and for the case of frame members - in Figs $10 \div 11$.

Capacity correction of the analysis forces is very important for seismic shear resistance of beams, columns and shear walls. Some appalling examples of shear failure in columns from past earthquakes are presented in Fig. 12. 


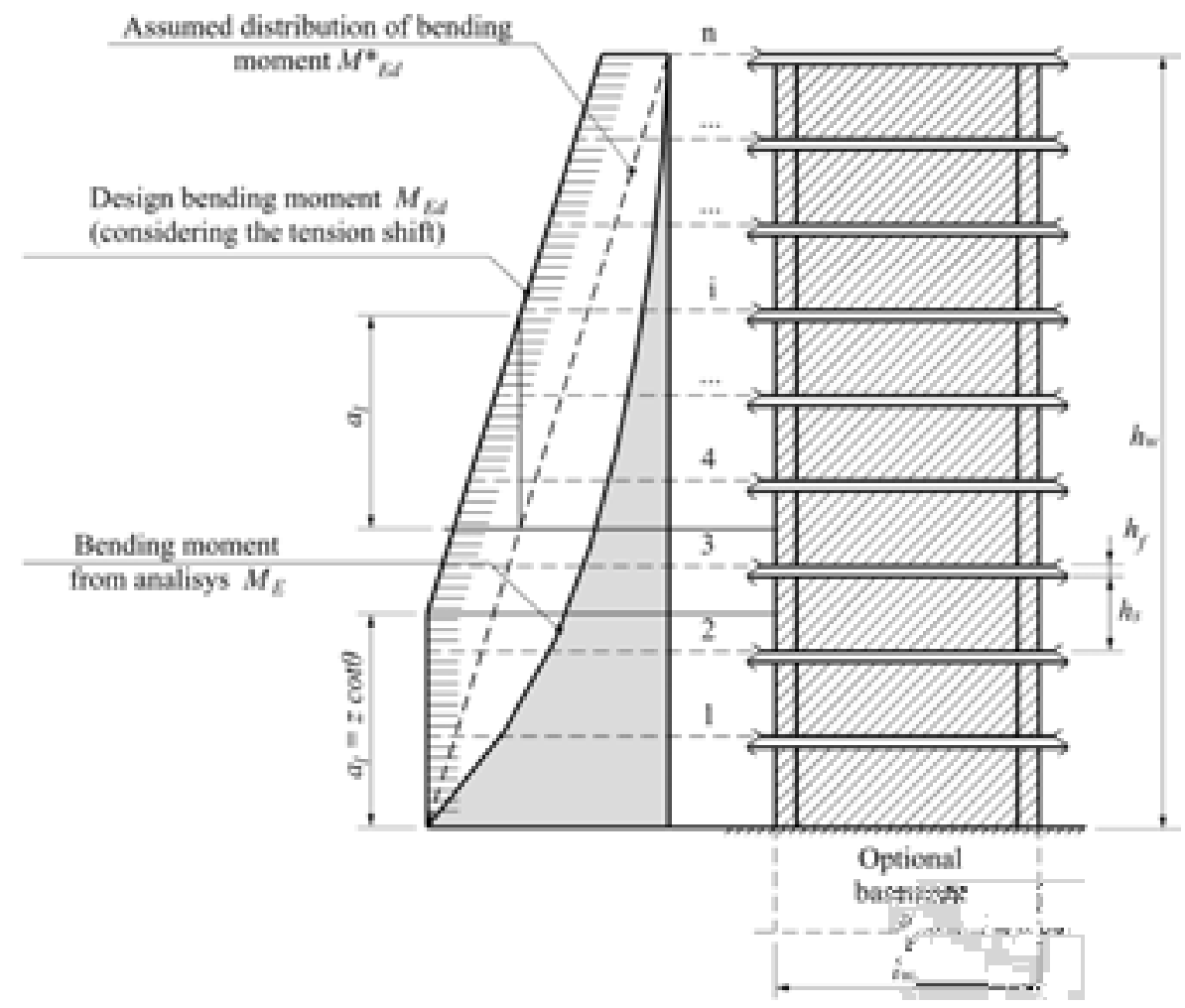

Fig. 8. Capacity corrected diagram of bending moments for a ductile wall

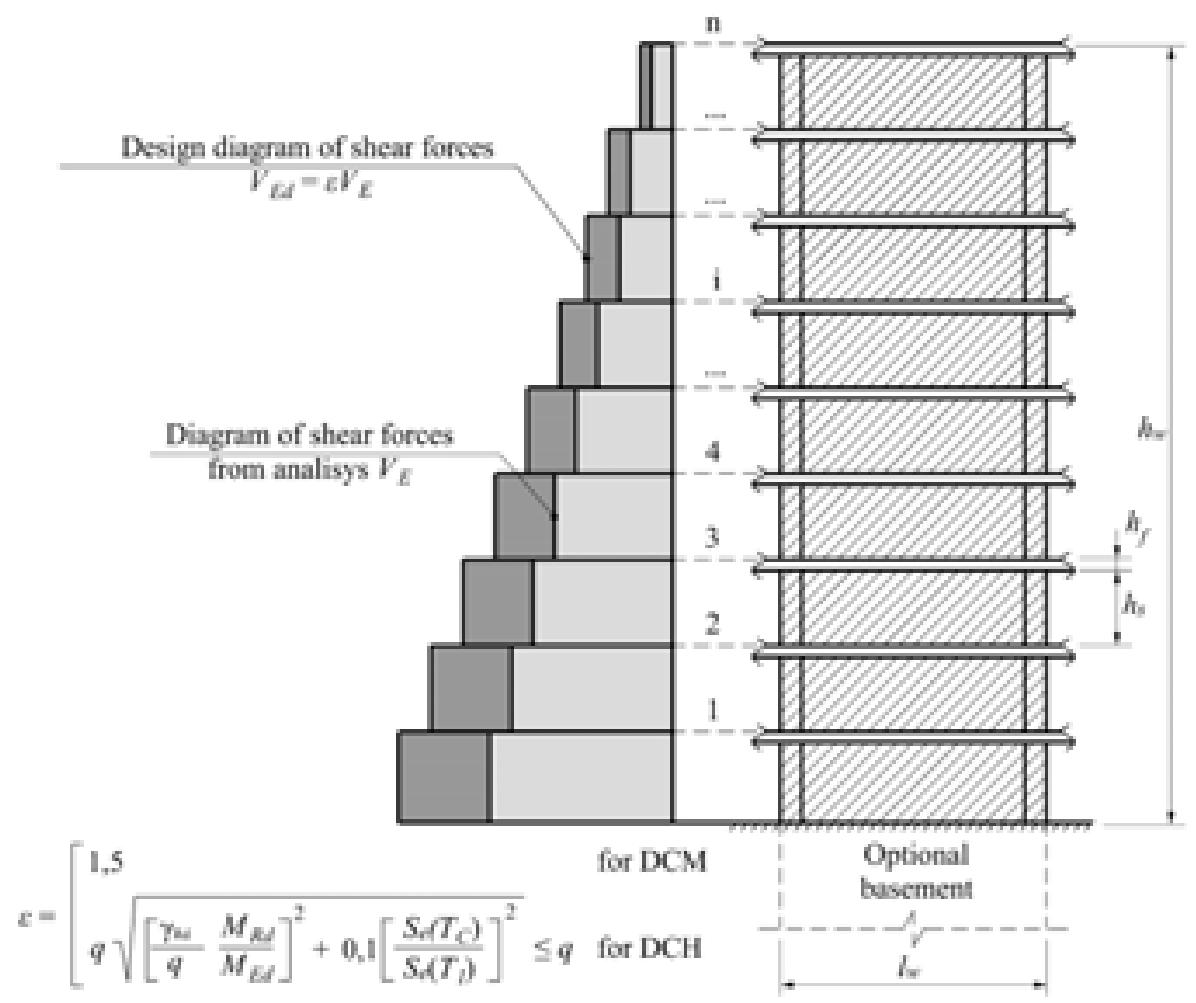

Fig. 9. Capacity corrected diagram of shear forces for a ductile wall 

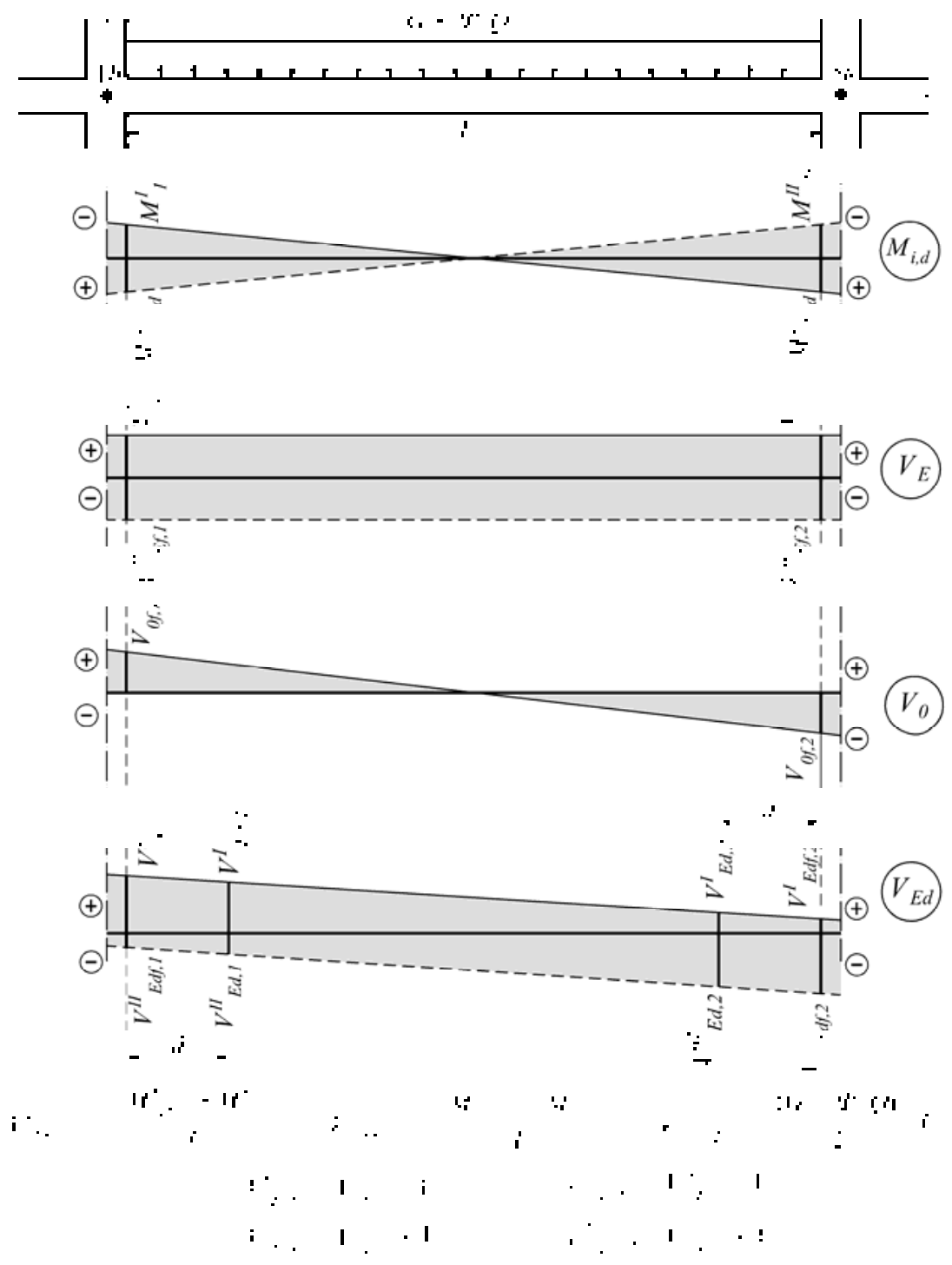

Fig. 10. Calculation of shear forces for beams, based on capacity design rules

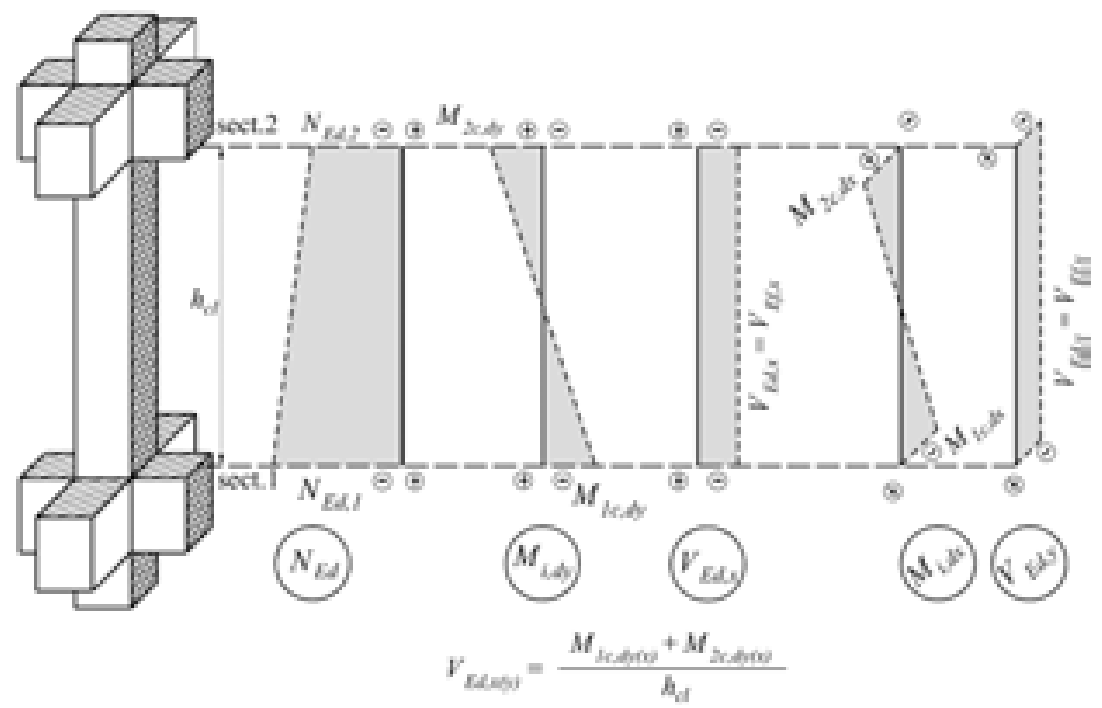

Fig. 11. Calculation of shear forces for columns, based on capacity design rules 


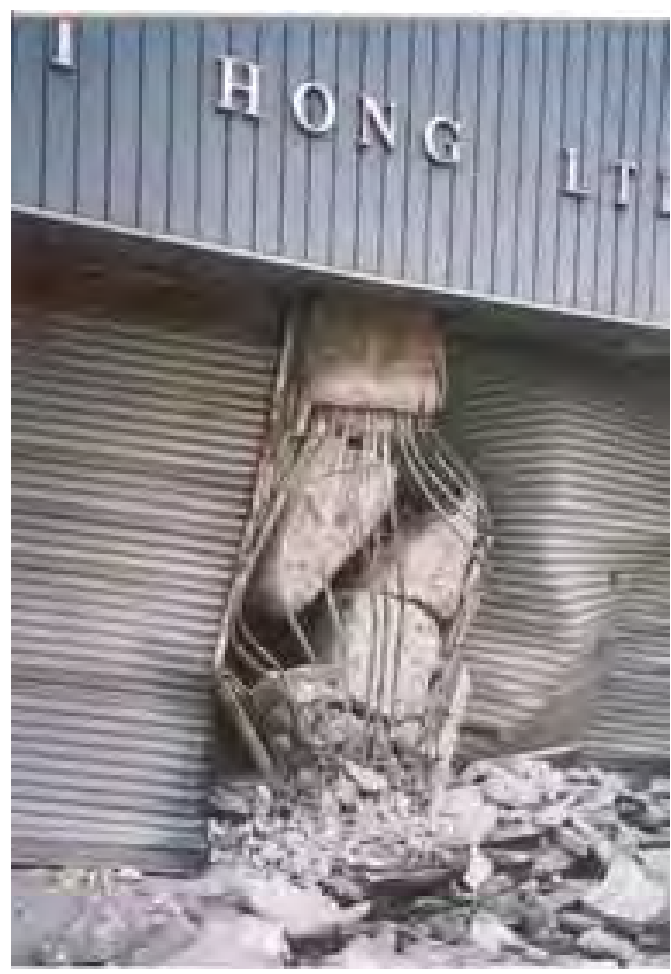

a) Kobe 1995

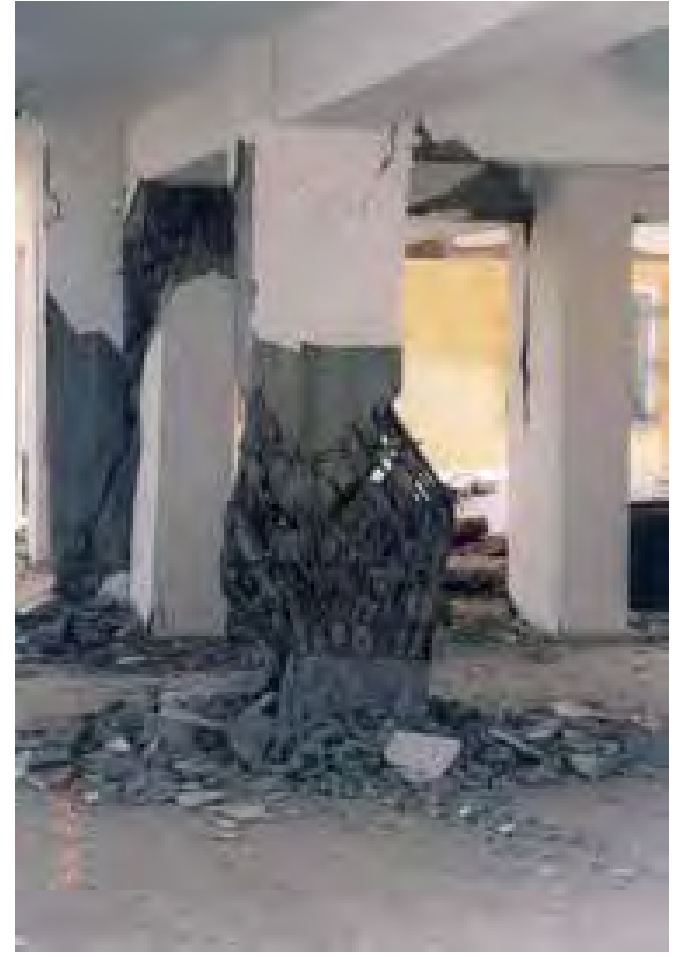

b) Turkey 1999

Fig. 12. Shear failure of columns due to insufficient shear resistance

\subsection{Wall structures with large lightly reinforced walls}

Eurocode 8 defines a new type of wall for Bulgarian construction practice - Large lightly reinforced wall (LLRW), which could be applied in the wall type of structures. That type of wall effectively dissipates energy by rocking effect. However Eurocode 8 fails to completely take into account the favourable effect of rocking and therefore the behaviour factor of structural systems as well in which LLRW is included which is probably too low. The definition of LLRW and systems in which such walls are included are presented in Figs $13 \div$ 15.

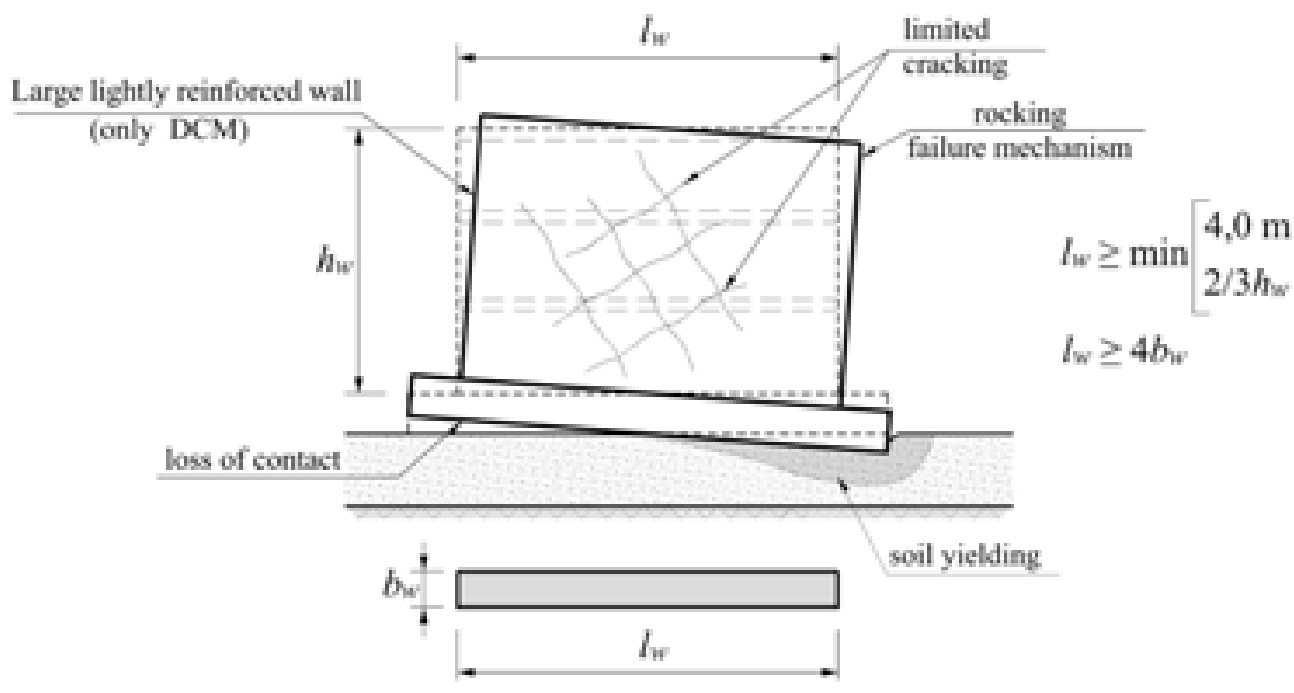

Fig. 13. Failure mechanism of large lightly reinforced walls 




Fig. 14. Vertical section of a typical LLRW system

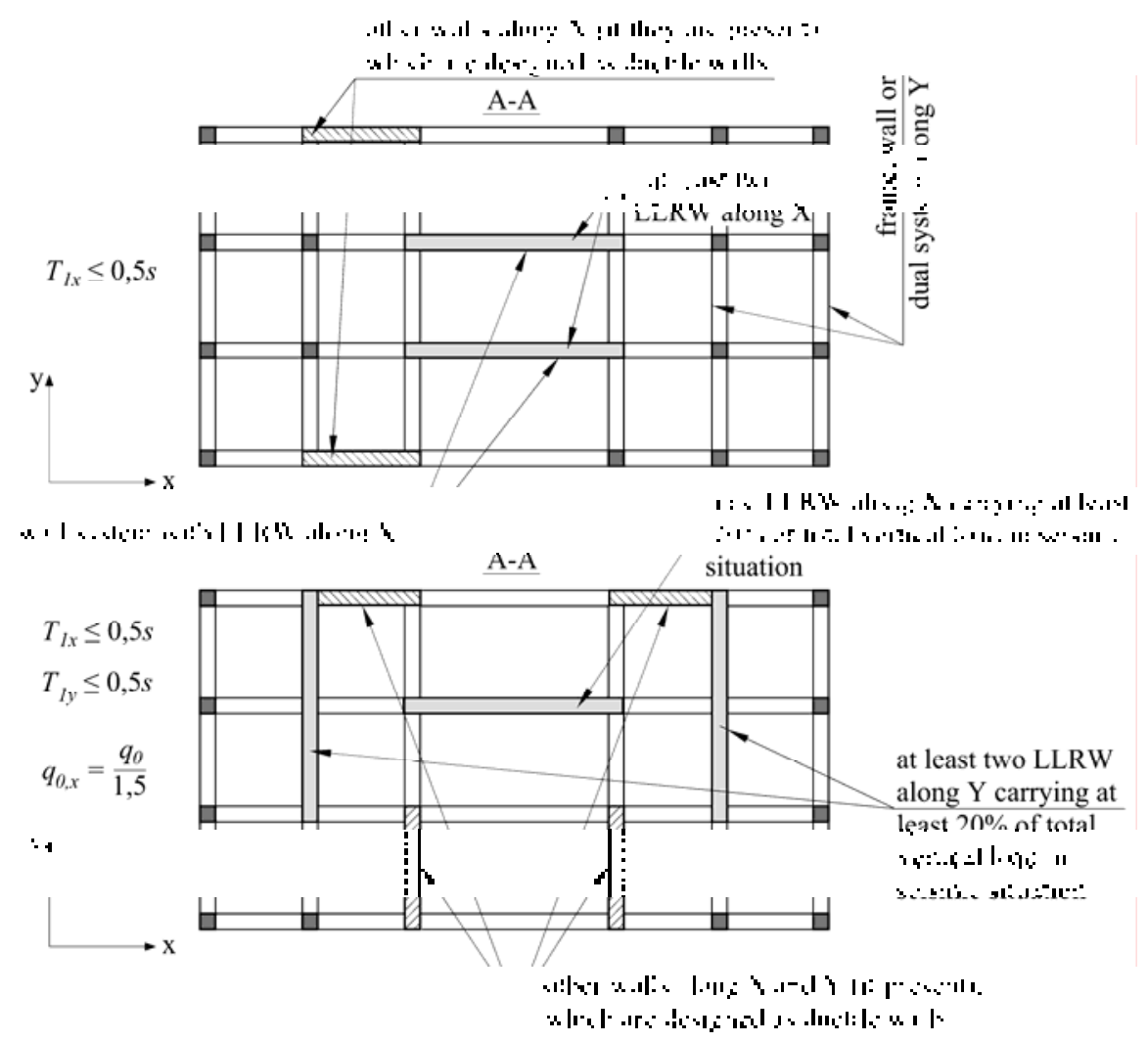

Fig. 15. Plan view of structural system LLRW is included

\subsection{Primary and secondary seismic elements}

The concept of primary and secondary elements is implemented in Eurocode 8. The secondary elements are not a part of the seismic structure. Their strength and rigidity could be neglected during the seismic analysis. However the whole contribution of the secondary elements to the rigidity of the structure for horizontal loading should not exceed $15 \%$ of the rigidity of all primary elements. Typical examples for secondary elements are the columns of RC wall type of buildings with flat slabs. Those elements and their connections should be designed to resist the vertical loading when they are subjected to the most unfavourable displacements by the seismic action. It is disallowed to classify some elements as secondary ones if they change structural type from torsionally flexible into some other. However Eurocode 8 provides some unclear instructions how to calculate the action effects of secondary elements in seismic design situation. A proposal for calculation of action effects in columns of $\mathrm{RC}$ wall type of buildings with flat slabs in seismic design situation is given in Fig 16. 


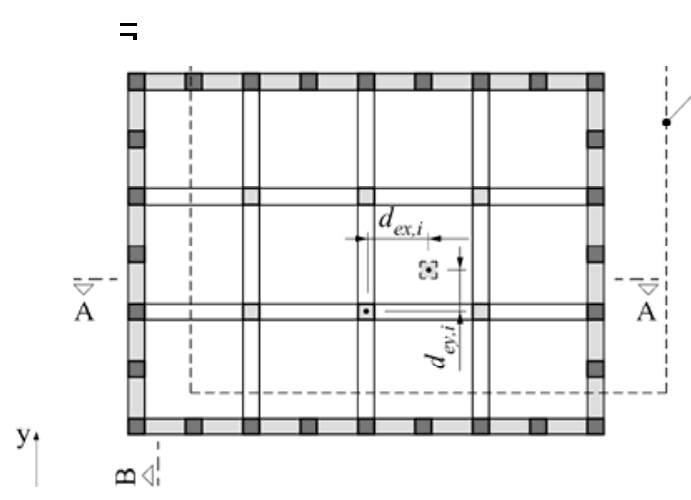

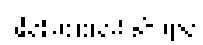

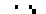

1. -

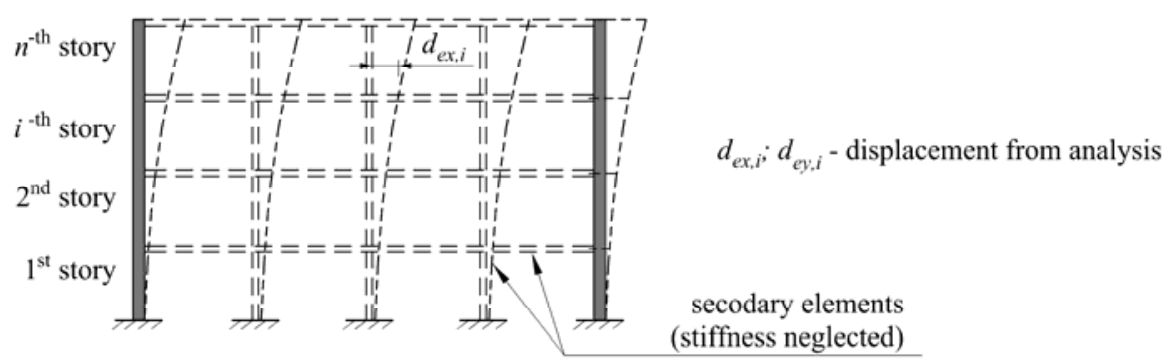

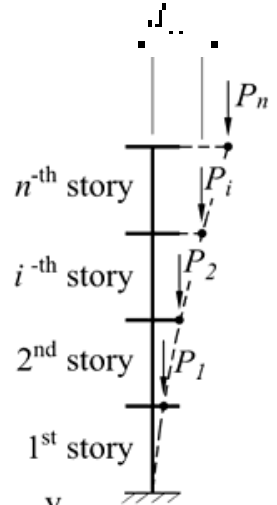

y,

$$
4
$$

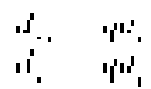

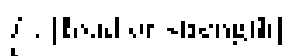

s.."
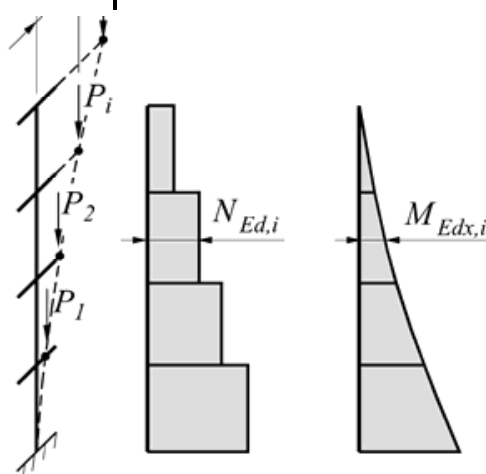

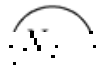

$\overparen{4 r}$
B-B



(stiffness neglected)

$r$



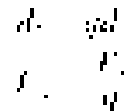

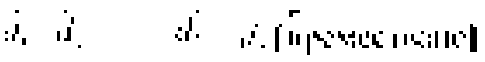

Fig. 16. Example of calculation of design action effects in secondary elements according to Eurocode 8 


\section{PROBLEMS AND SOLUTIONS IN THE DESIGN OF RC WALL STRUCTURES}

\subsection{Shear design and commentary on the} inclination of the compression strut

One of the major difficulties for application of $\mathrm{DCH}$ for the wall type of structures is too strict requirements for the shear resistance check on compression strut. The definition of this check is presented in Fig. 17. The Eurocode 8 has very high requirements for shear design

of walls. An example of shear wall reinforcement of the example building presented in Fig.6 is shown in Fig. 18. However the underestimating of shear design of walls leads to the collapse as that presented in Fig. 19.

$$
V_{E d, i} \leq\left\{\begin{array}{lll}
V_{R d, \max }=0,5 \alpha_{c w} b_{w o} z & v_{1} f_{c d} & \text { - above critical region } \\
V_{R d, \max }=0,2 \alpha_{c w} b_{w o} z & v_{1} f_{c d} & \text { - in critical region }
\end{array}\right.
$$

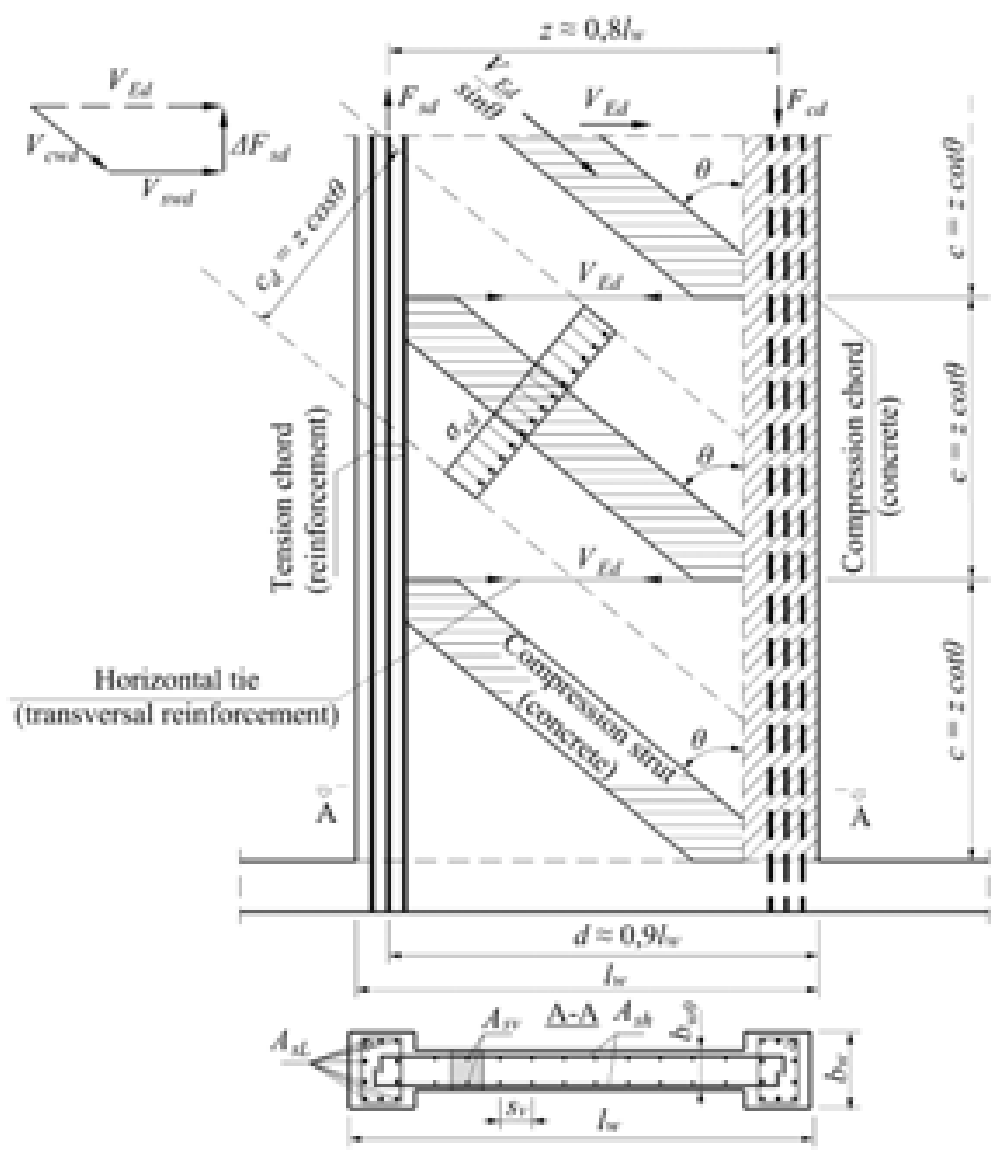

Fig. 17. Truss model for shear design of walls 


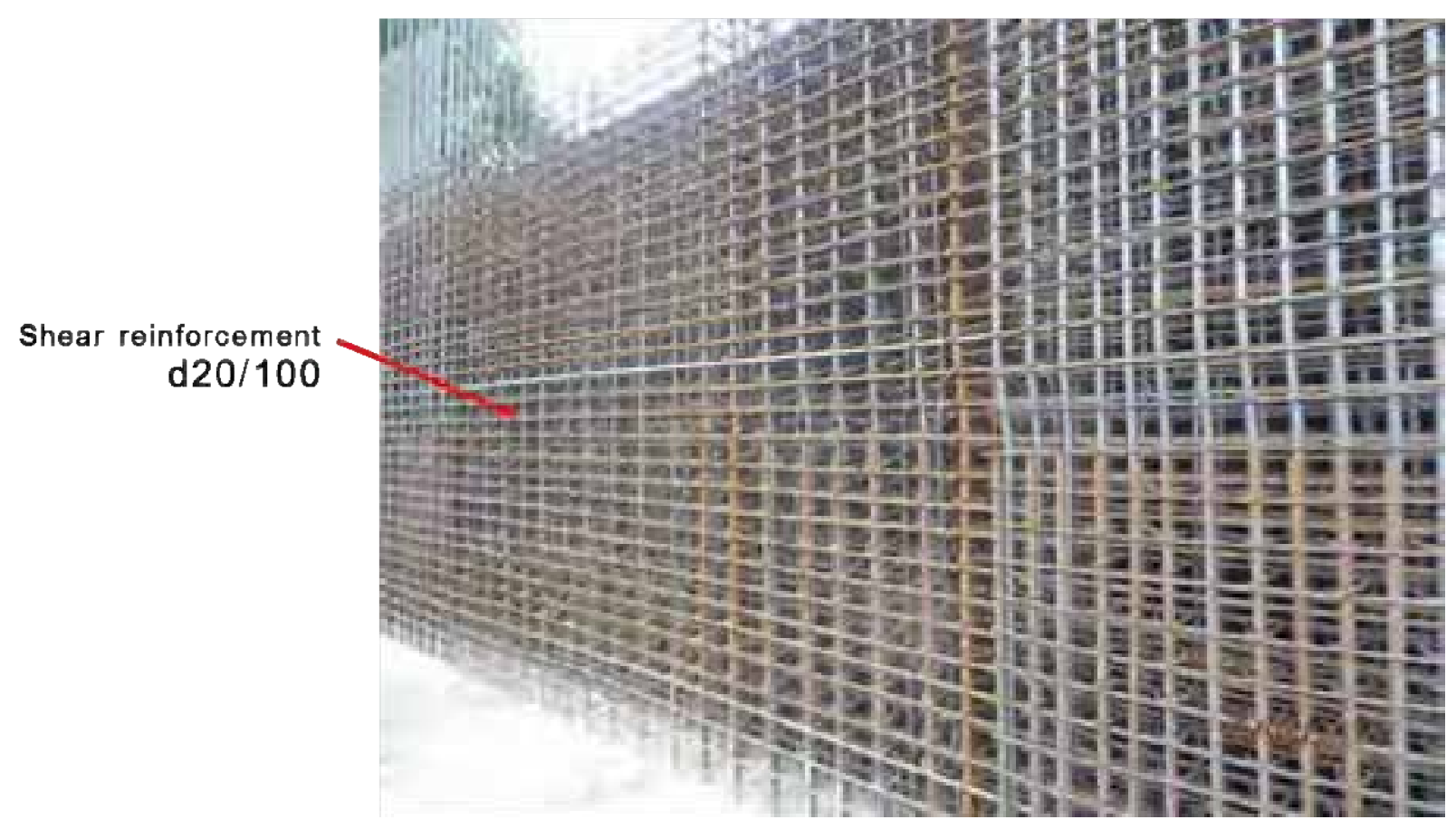

Fig. 18. Shear reinforcement in a wall designed according to Eurocode 8

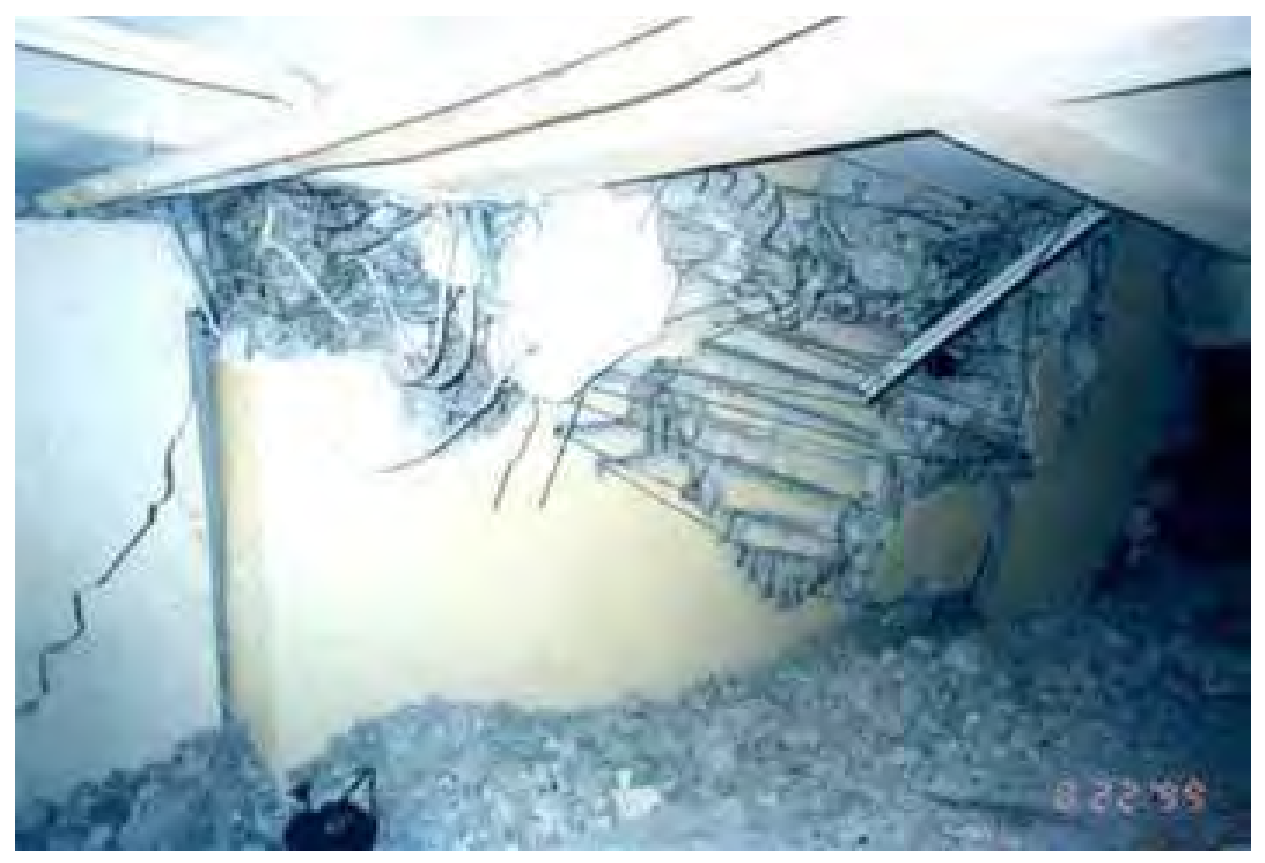

Fig. 19. Heavy damaged shear wall during the earthquake in Turkey 1999

\subsection{Local ductility requirements and checks}

Local ductility of ductile walls is ensured by providing the confined boundary elements in the critical zone of the wall. However the procedure for calculation of the length of confined boundary elements is complicated and is partly clear in Eurocode 8 even for the case of walls with rectangular cross section. In author's opinion the procedure is iterative even for the simple cases.
Some proposals for procedures for local ductility calculations for walls with rectangular and composite section are given bellow in Figs $20 \div 21$. An example of confining reinforcement for wall structures with composite cross section designed according to Eurocode 8 is shown on Fig. 22. 


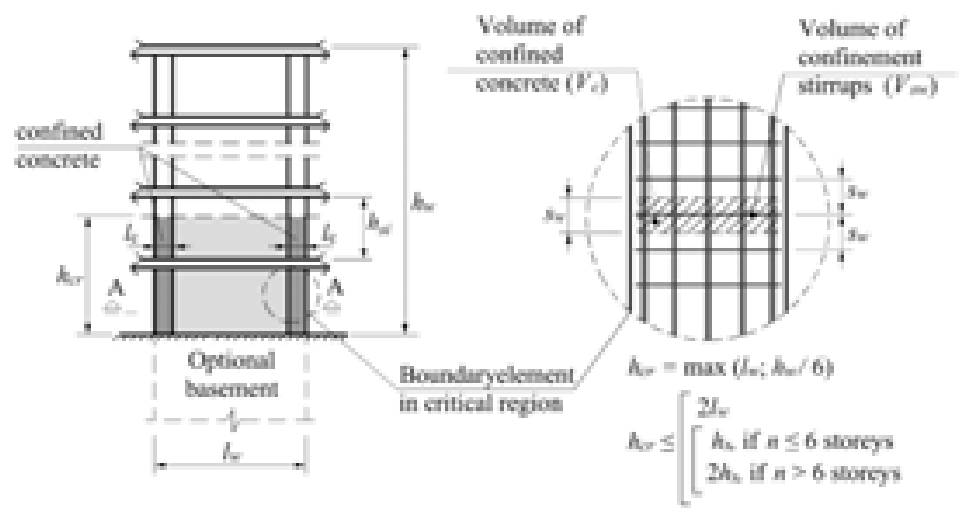

1. $X_{u}=\left(v_{d}+\omega_{v}\right) \frac{l_{w} b_{w o}}{b_{o}} ;$

2. The length of the boundary element is assumed and confinement reinforcement is detailed;

3. $\varepsilon_{c u 2, c}=0.0035+0.1 \alpha \omega_{w d}$

4. $l_{c}=X_{u}\left(1-\frac{\varepsilon_{c u 2}}{\varepsilon_{c u 2, c}}\right)$

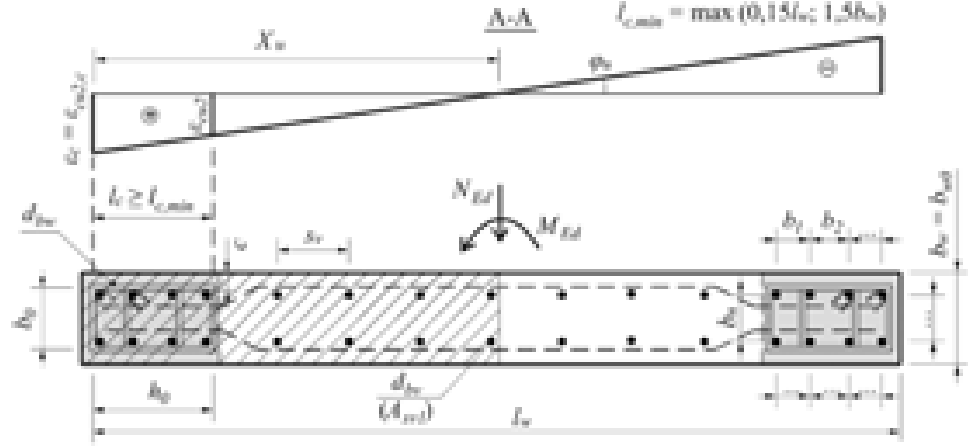

5. $l_{c} \geq l_{c, \min }=\max \left[\begin{array}{c}0.15 l_{w} \\ 1.5 b_{w}\end{array}\right.$

Steps from 1. to 5 . are repeated if required

Fig. 20. Calculation of the length of boundary elements based on the requirements for local ductility
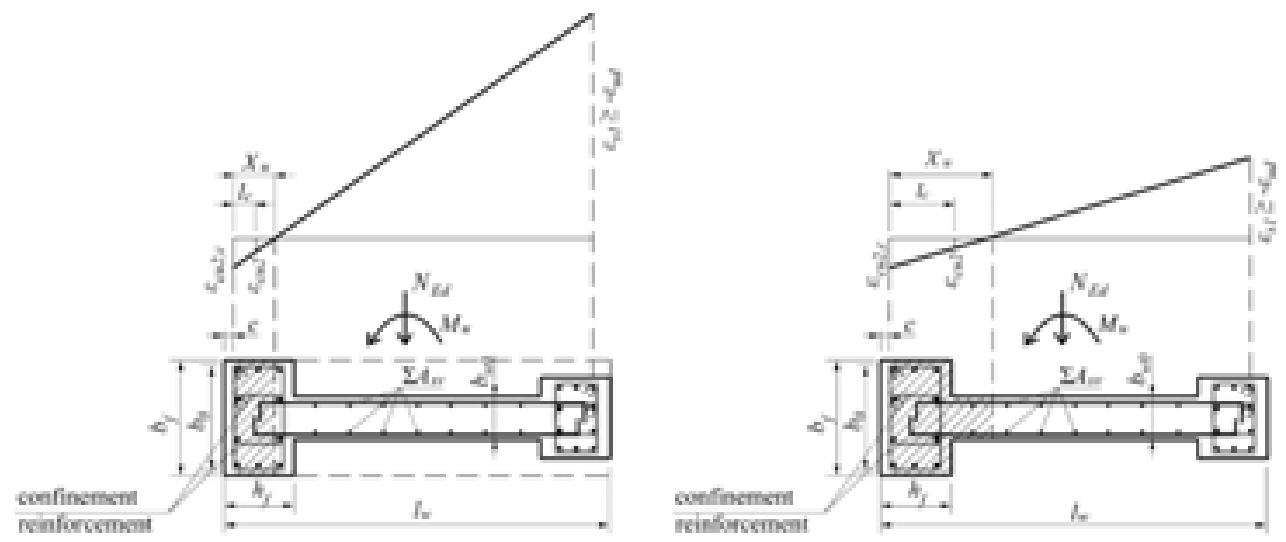

1. $X_{u}=\left(v_{d}+\omega_{v}\right) \frac{l_{w} b_{w o}}{b_{o}}$;

2.1 If $X_{u} \leq h_{f}$

the above procedure for rectangular section is applied assuming $b_{w}=b_{f}$
2.2 If $X_{u}>h_{f}$ the following iterative solution is proposed:

a) Confinement reinforcement is detailed and boundary elements length is assumed;

b) Equilibrium state at yield curvature is inspected and $x_{y}$ and $y$ are calculated;

c) Equilibrium state at maximum curvature is inspected and $x_{y}$ and $y$ are calculated;

d) Curvature ductility ratio $\mu$ is determined

$$
\mu_{\phi}=\frac{\phi_{u}}{\phi_{y}} \geq \begin{cases}2 q_{o}\left(\frac{M_{E d}}{M_{R d}}\right)_{\max }-1 & \text { ако } T_{1} \geq T_{C} \\ 1+2\left(q_{0}-1\right) T_{C} / T_{1}\left(\frac{M_{E d}}{M_{R d}}\right)_{\max } & \text { ако } T_{1}<T_{C}\end{cases}
$$

e) Steps from a) to d) are repeated if required

Fig. 21. Fulfilment of local ductility requirements for composite wall sections 


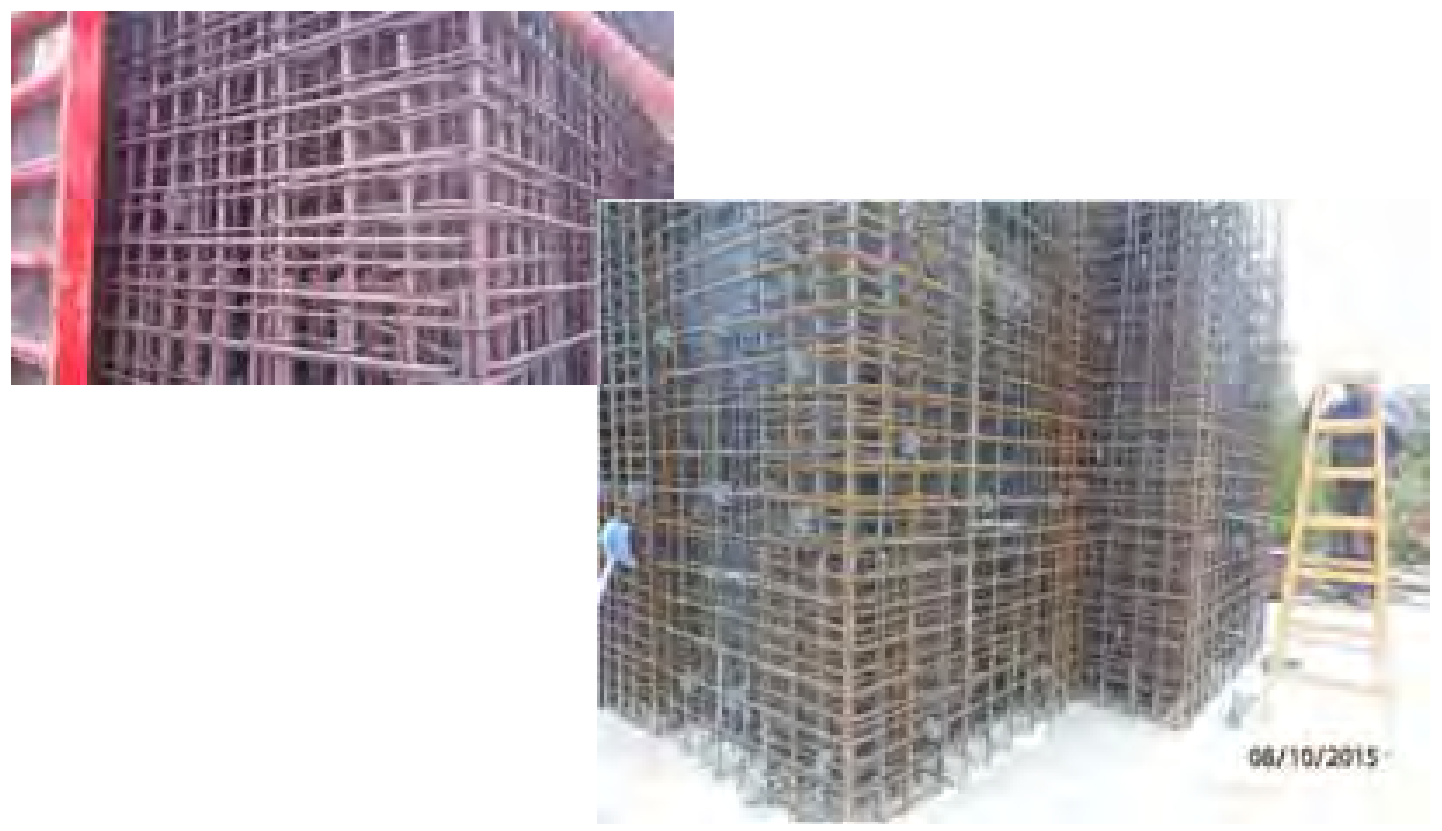

Fig. 22. The confining reinforcement of wall with composite section designed according to Eurocode 8 (note the example building presented on Fig. 6 and Fig. 7

\subsection{Detailing requirements}

The detailing requirements of Eurocode 8 for ductile walls are given in Figs. $23 \div 24$. Some special attention should be paid to detailing confined boundary elements in critical zone. An example for detailing shear walls with

dumbbell cross-section is presented in Fig. 25. That shear wall is designed according to Eurocode 8 and it is from the example building shown in Fig. 6 and Fig. 7.
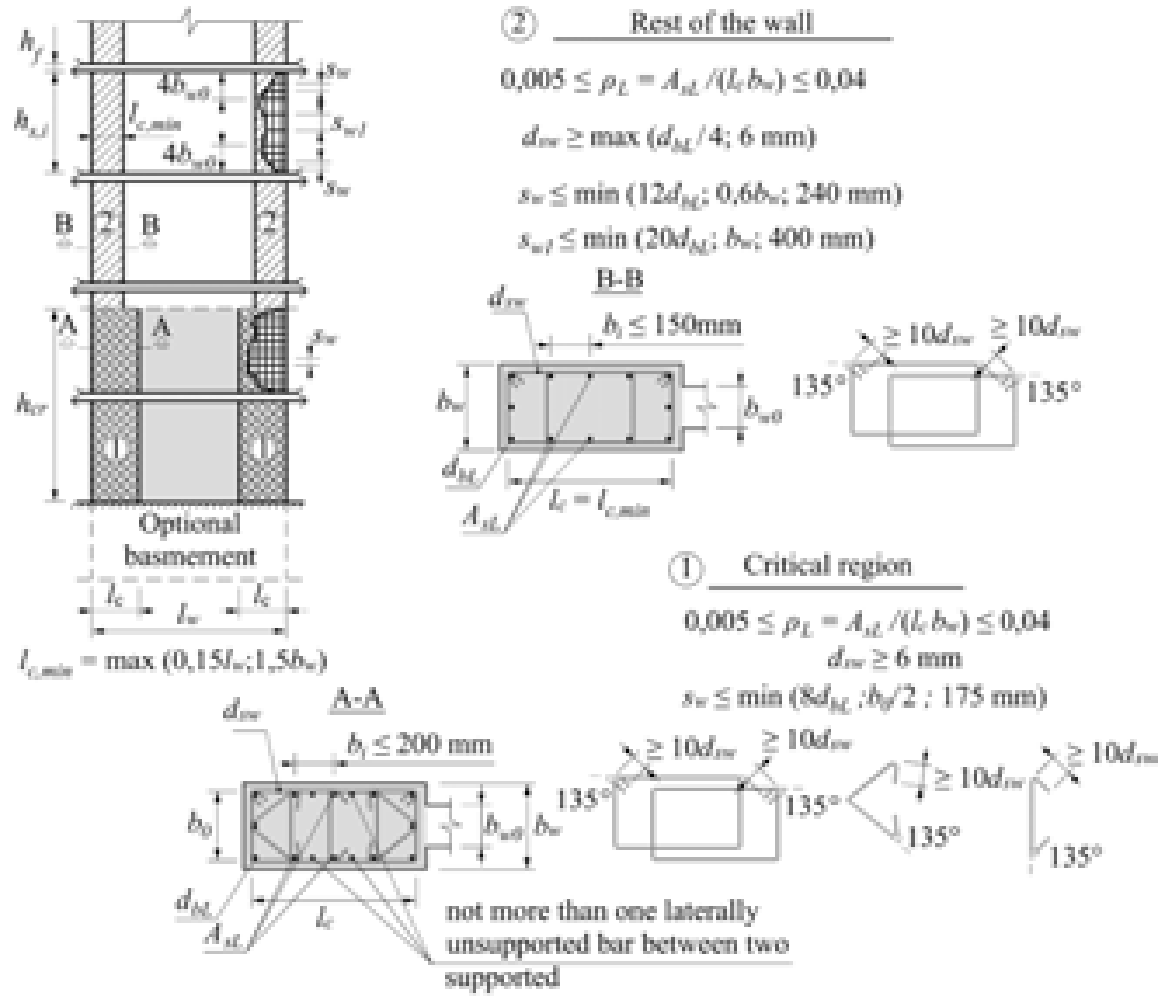

Fig. 23. Reinforcement detailing requirements for DCM

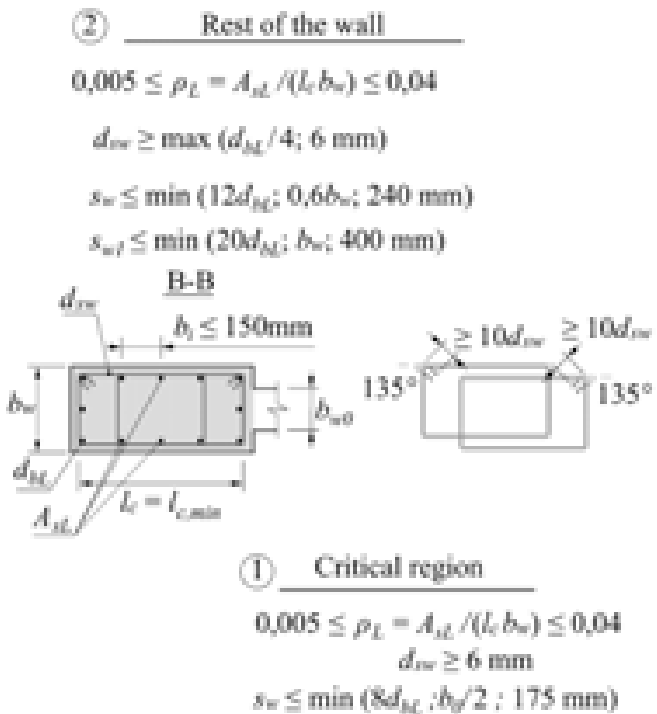

$s_{*} \leq \min \left(8 d_{N} ; b / 2 ; 175 \mathrm{~mm}\right)$ 


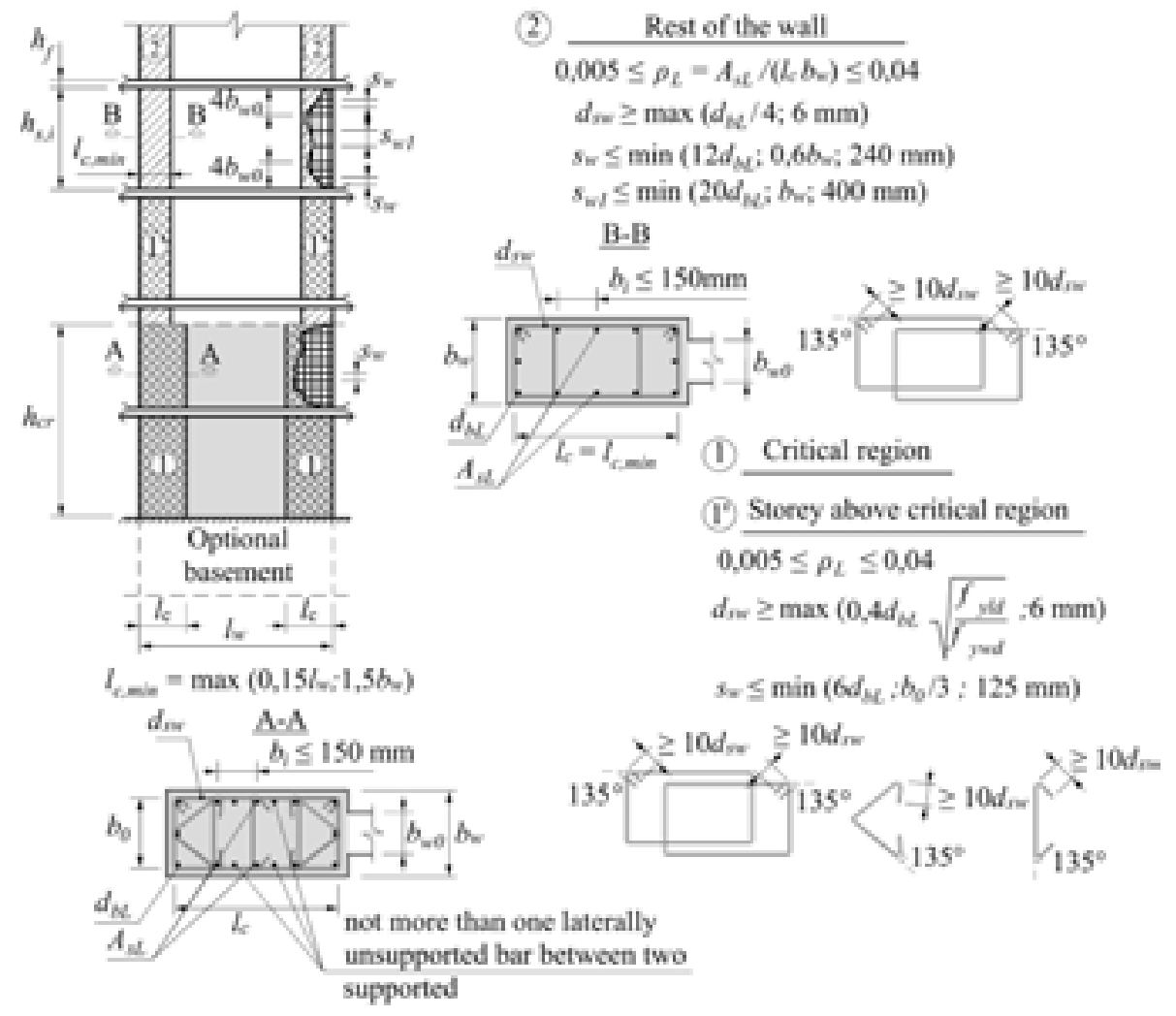

Fig. 24. Reinforcement detailing requirements for $\mathrm{DCH}$

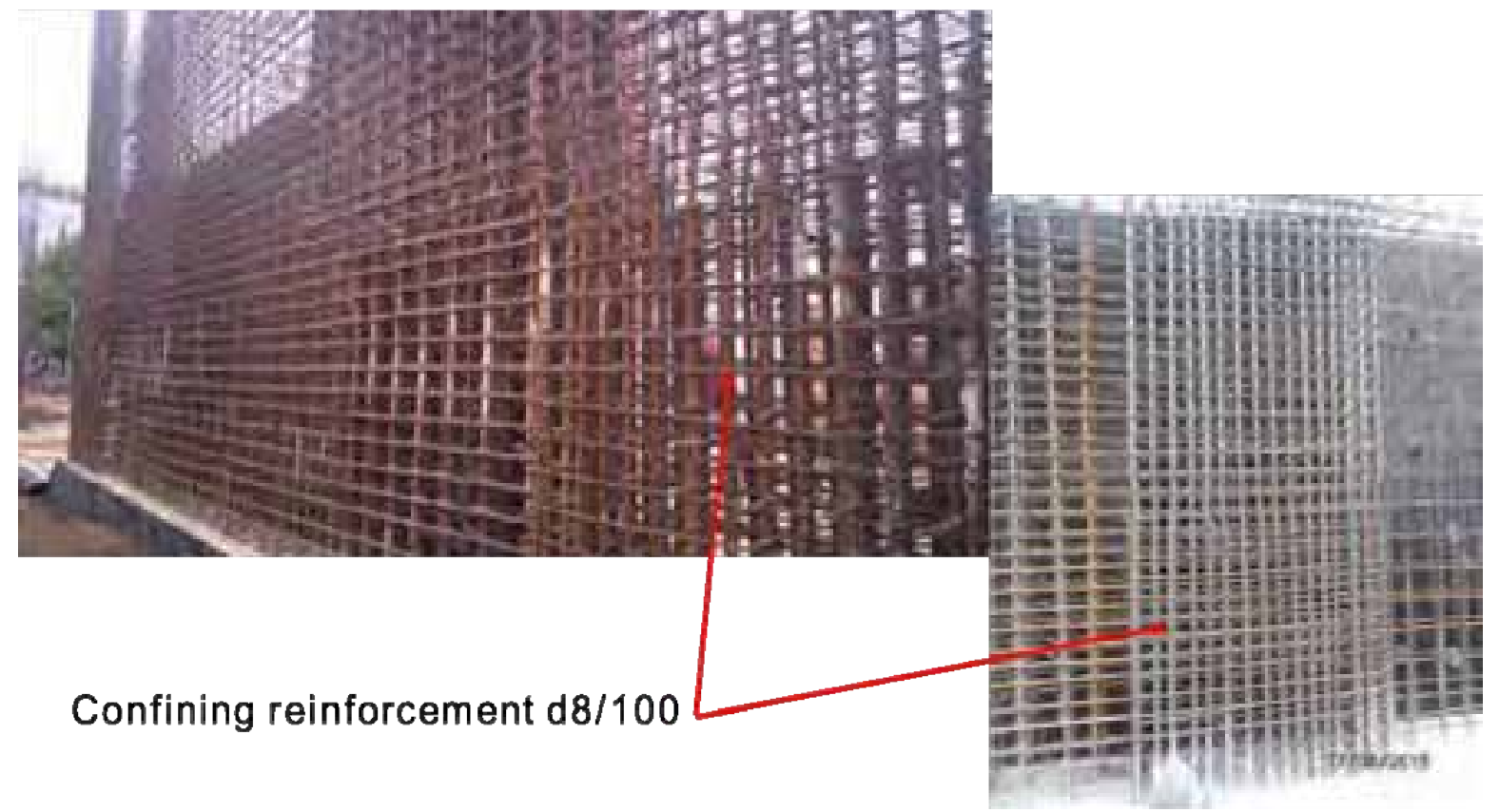



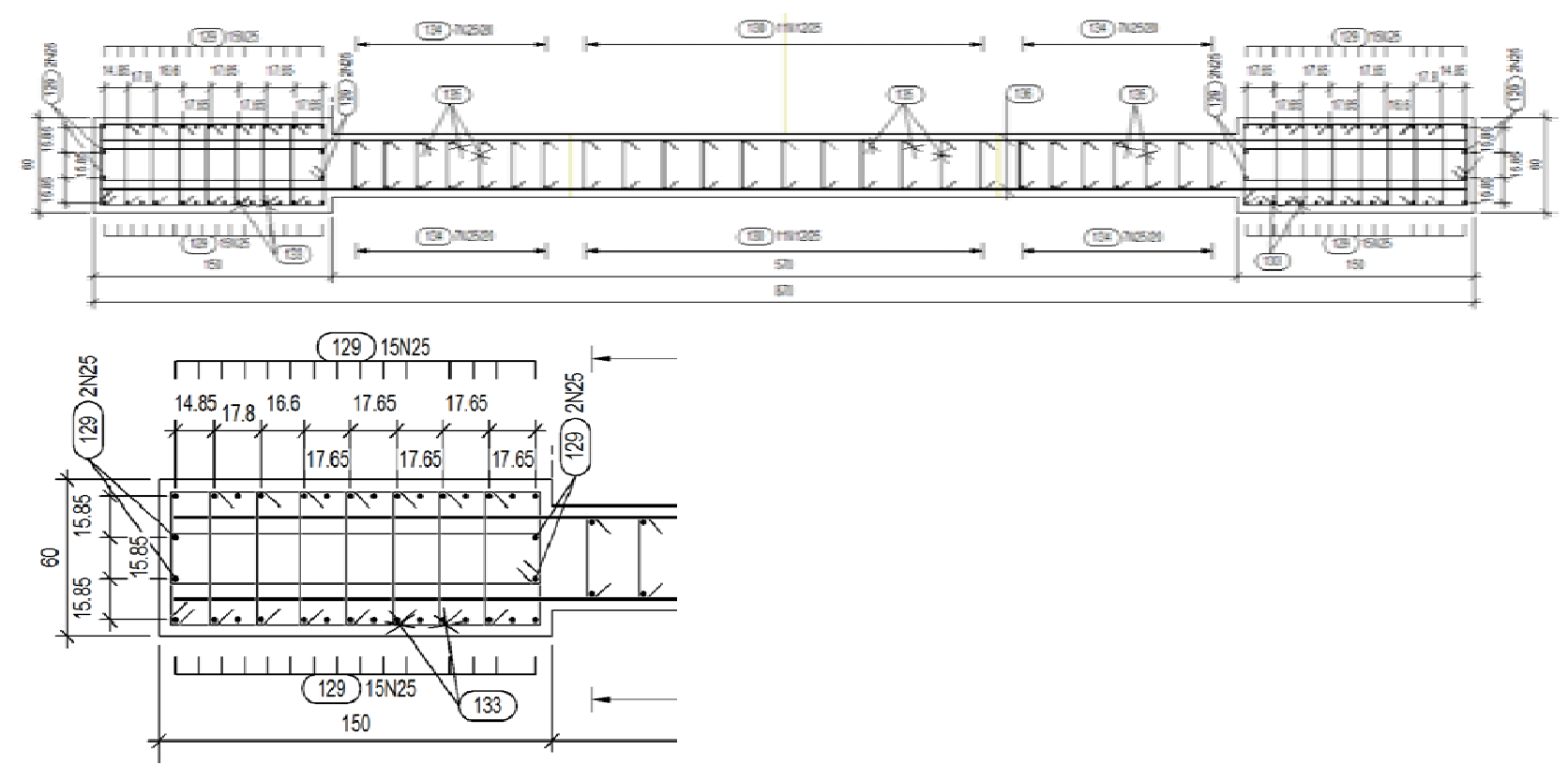

Fig. 25. An example for detailing shear wall with dumbbell cross section designed and detailed according to Eurocode 8

\section{PROBLEMS AND SOLUTIONS IN THE DESIGN OF RC FRAME STRUCTURES}

\subsection{Strong columns-weak beams design philosophy}

The "strong columns - weak beams" concept is major issue in seismic design of frame structures according to Eurocode8. That concept is presented in Figs. $26 \div 27$.

The fulfilment of the capacity design rule "strong columns - weak beams" is very important for seismic

design of frame structures. An example of braking that rule and its consequences are presented in Fig. $28-a$ total collapse of building.

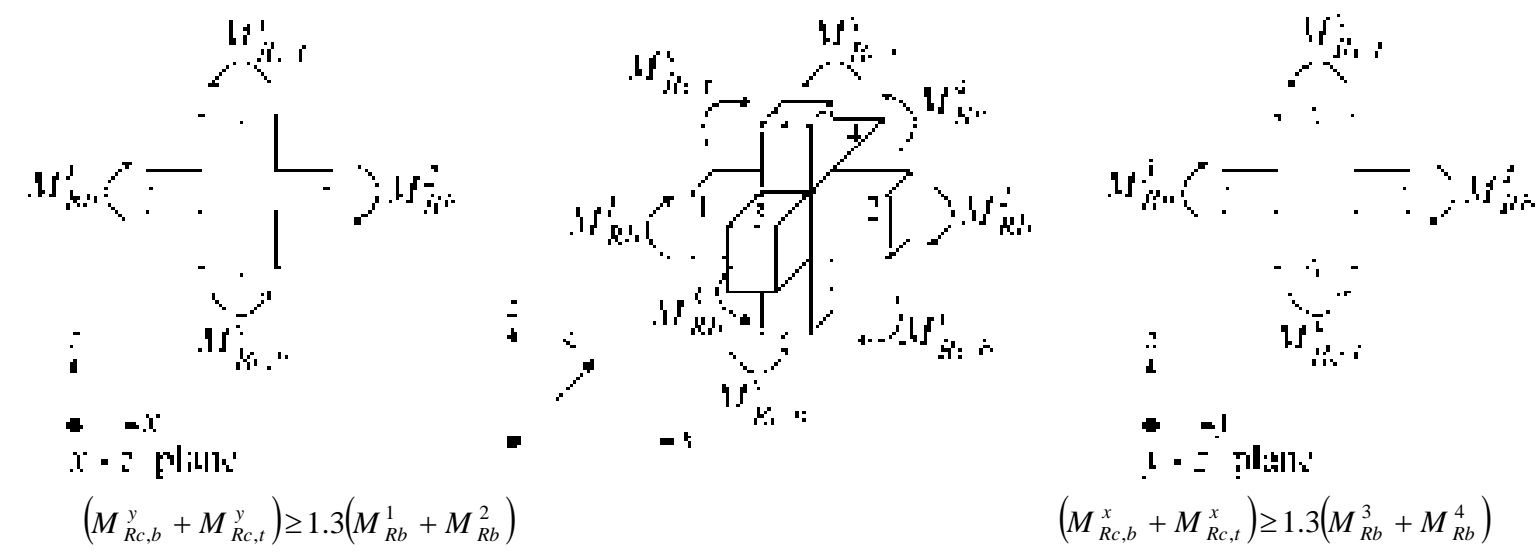

Fig. 26. Verification of "weak beams strong columns" requirement in beam column joints 


$$
\begin{aligned}
& \Sigma M_{R c}^{\prime}=M_{R c t}^{\prime}+M_{R c b}^{\prime} \\
& \Sigma M_{R s}^{\prime}=M_{R s i}^{\prime}+M_{R b r}^{\prime}
\end{aligned}
$$

If $\sum M_{R B}^{f}<\sum M_{R c}^{\prime}$ - plastic hinges are formed in beams

$$
\begin{aligned}
& \approx M_{R c, b}^{\prime} \frac{\Sigma M_{R b}^{\prime}}{\Sigma M_{R c}^{l}}
\end{aligned}
$$

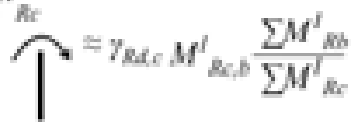

$$
M_{R=1,}^{i}
$$

note, that verifications are made for the two opposite directions of seismic action

If $\sum M_{R s}^{l}>\sum M_{R c}^{l}-$ plastic hinges are formed in columns

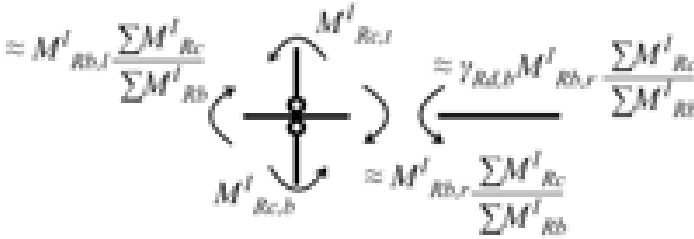

$$
\begin{aligned}
& \overbrace{\gamma_{\text {Rad }} M_{\text {Res }}}
\end{aligned}
$$

\section{E}

direction of seismic action

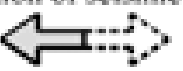

Fig. 27. Calculation of end section moments in beams and columns depending on location of plastic hinges
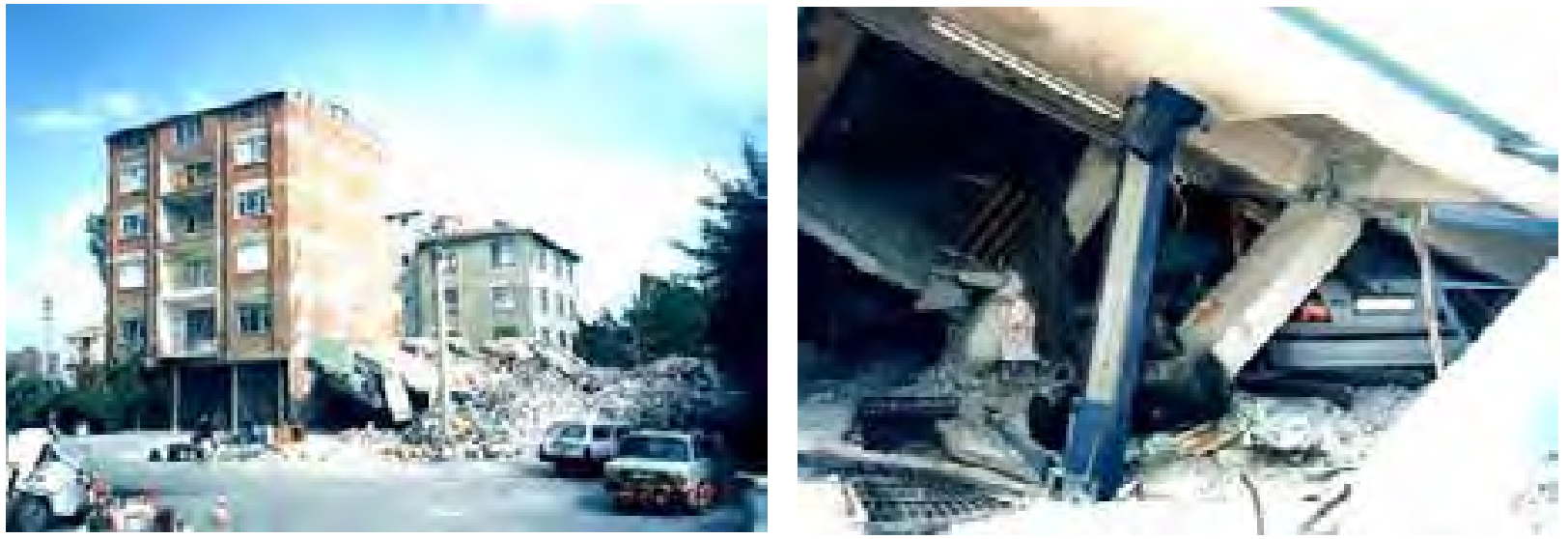

Fig. 28. Total collapse of a building due to "week columns-strong beams" - Turkey 1999

\subsection{Local ductility requirements and checks}

Eurocode 8 is the comprehensive seismic code which has local ductility checks for columns which is based on the quantity of confining stirrups as well as on properties of the confined concrete. The procedure of
Eurocode 8 for the ductility checks of primary columns of frame structures is presented on Fig. 29. 


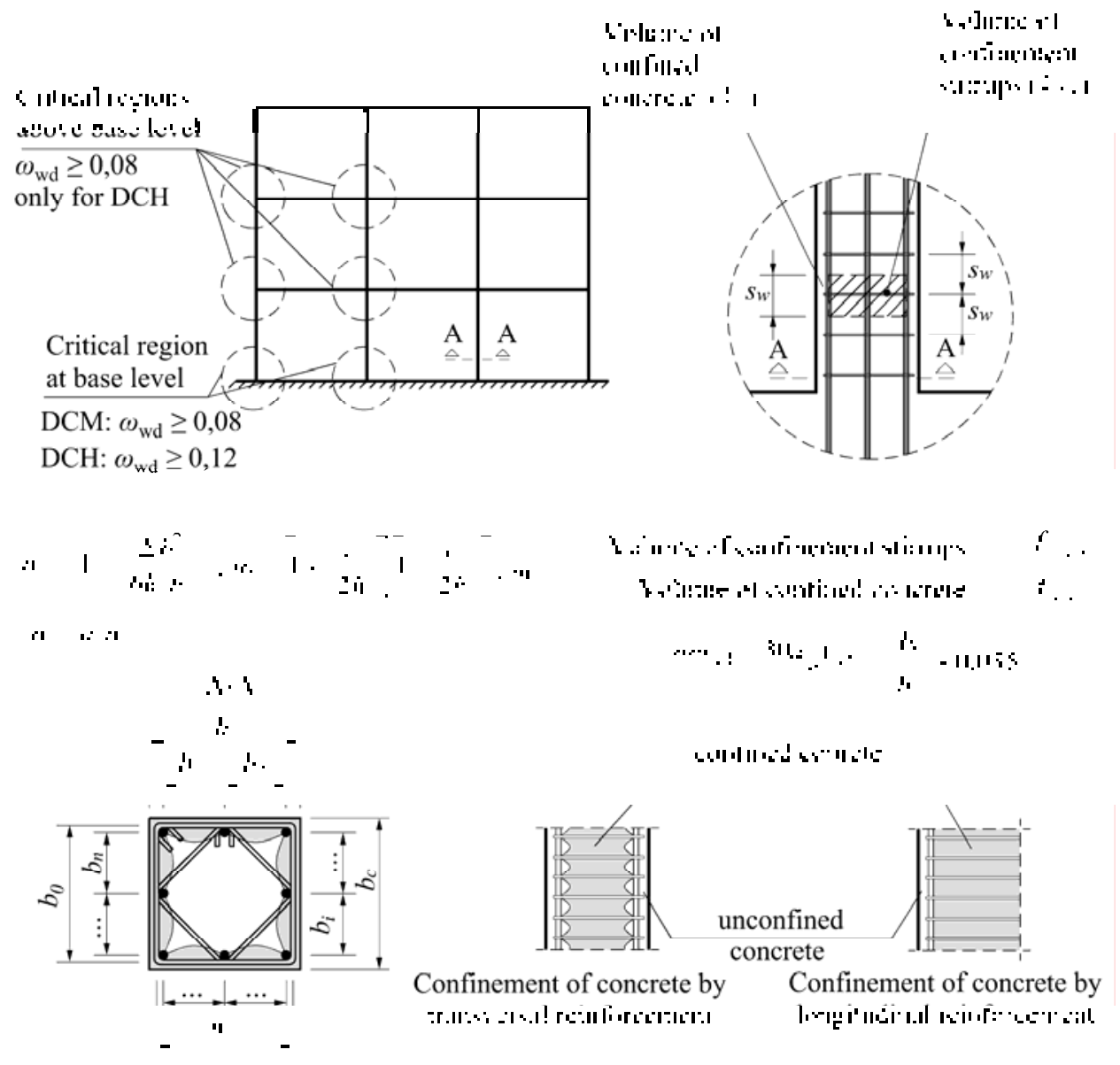

Fig. 29. Local ductility requirements for columns in seismic MRF

\subsection{Detailing requirements}

The detailing requirements of Eurocode 8 for primary beams and columns are given in Figs. $30 \div 33$. Some special attention should be paid to the reinforcement ratio of top beam reinforcement and diameter limitation on longitudinal bars which are bonded in beam-column joints.

It is very important to ensure $135^{\circ}$ hook for the stirrups in the beams, columns and walls. The experience of past earthquakes shows that damages are usually initiated from places where $90^{\circ}$ stirrups hooks are applied (please see Fig. 34).
For the case of columns the major problems are close clear distance between longitudinal bars especially in the lapping length as well as required distance between stirrups in the splicing length of longitudinal bars (see Fig. 35). The problem could be solved by splicing devices. However some special tests are required for them. An example of application of such devices is presented in Fig. 36. The building in which the devices were applied was designed and detailed according to Eurocodes.

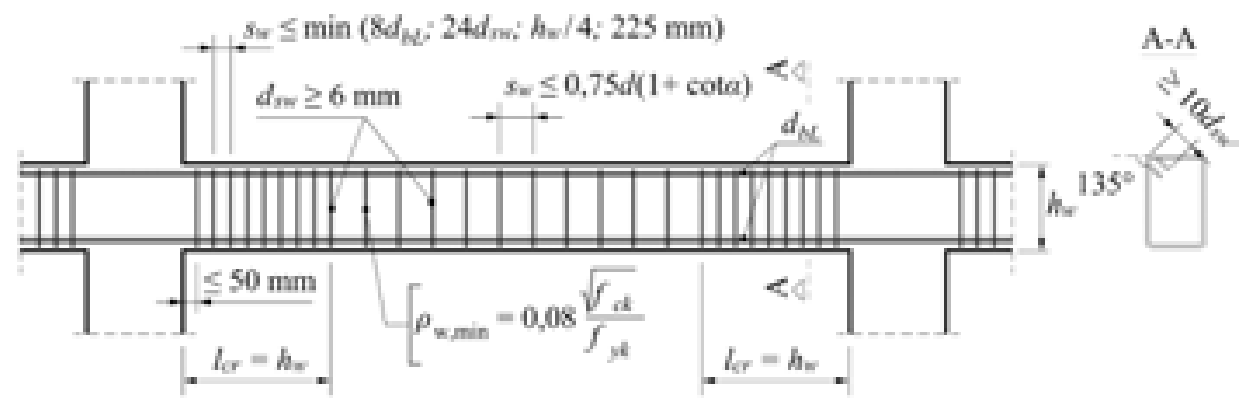

Fig. 30. Transversal reinforcement detailing requirements for beams in seismic MRF - DCM 

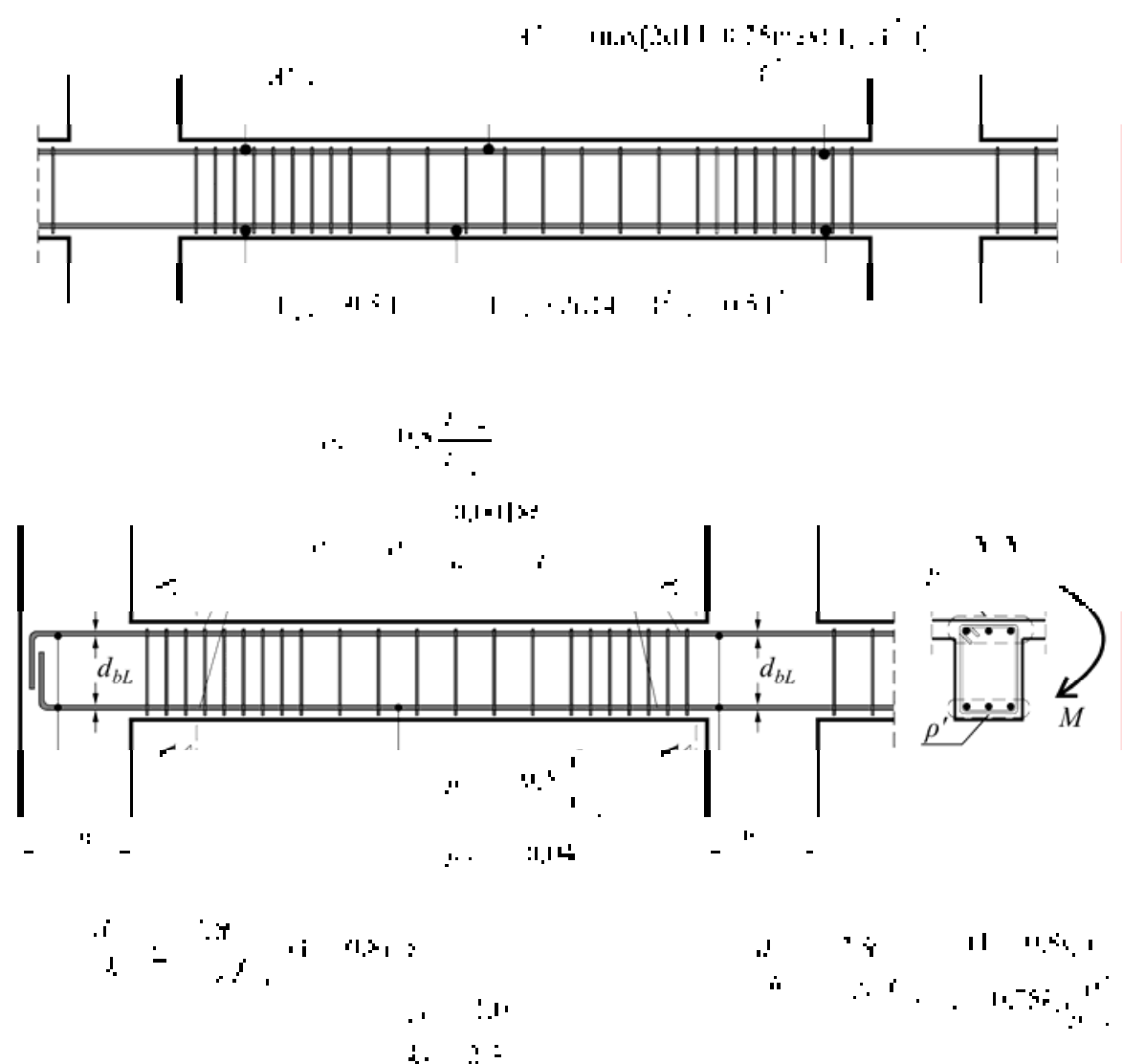

Fig. 31. Longitudinal reinforcement detailing requirements for beams in seismic MRF - DCM

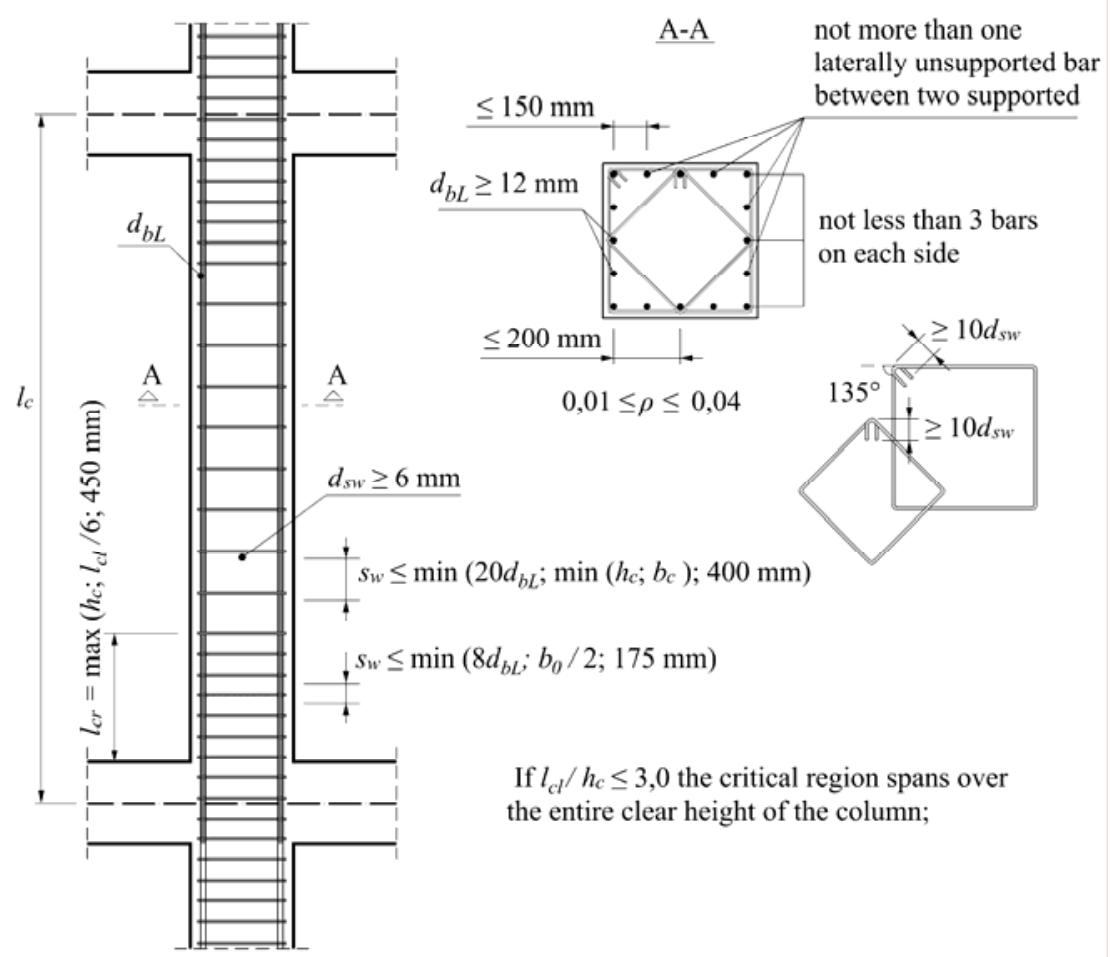

Fig. 32. Reinforcement detailing requirements for columns in seismic MRF - DCM 


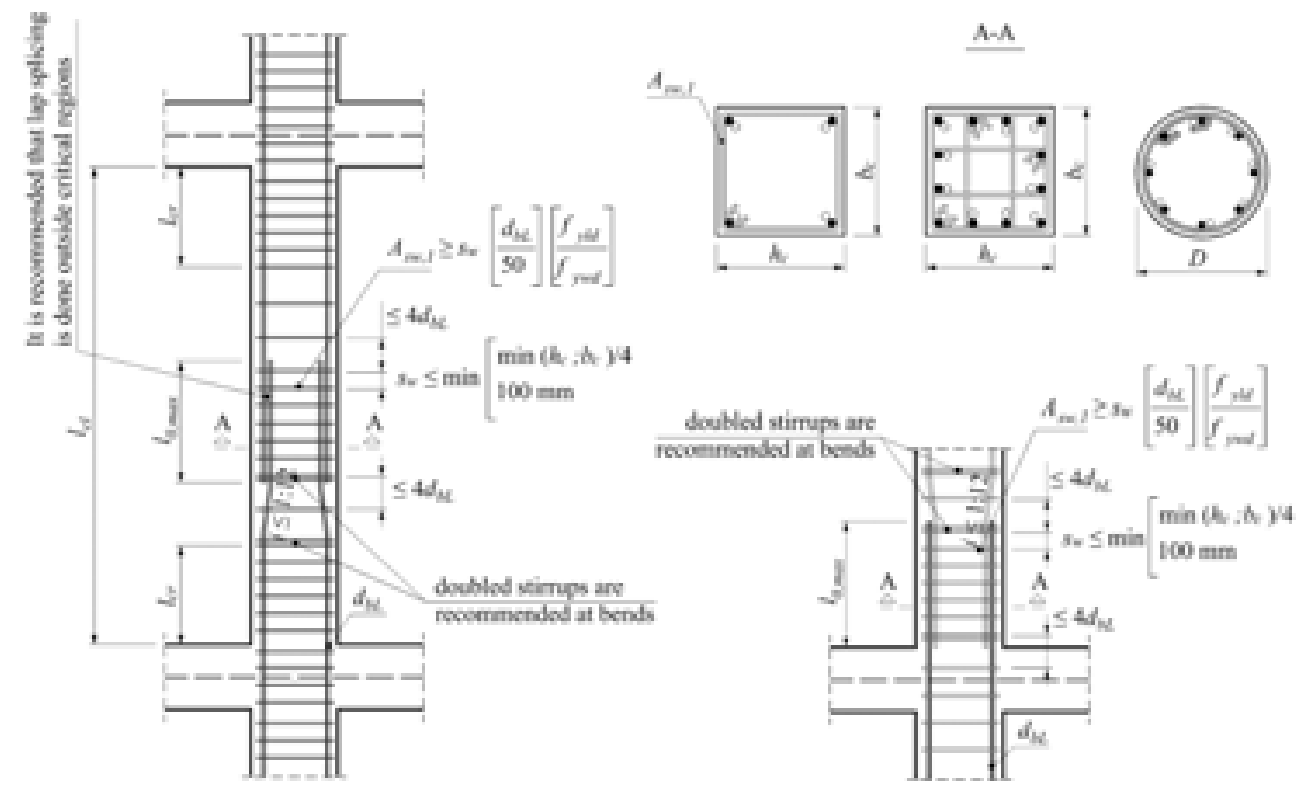

Fig. 33. Transversal reinforcement detailing requirements over the splicing length of the longitudinal reinforcement
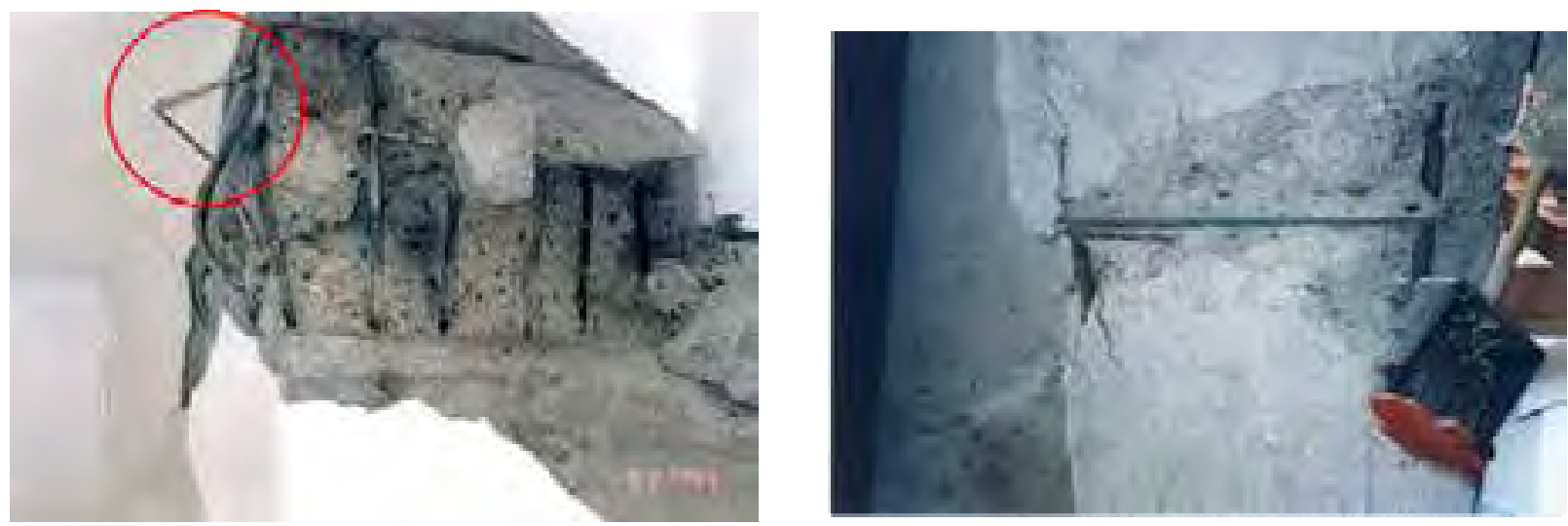

Fig. 34. Initiation of column failure due to $90^{\circ}$ hooks of stirrups - Turkey 1999
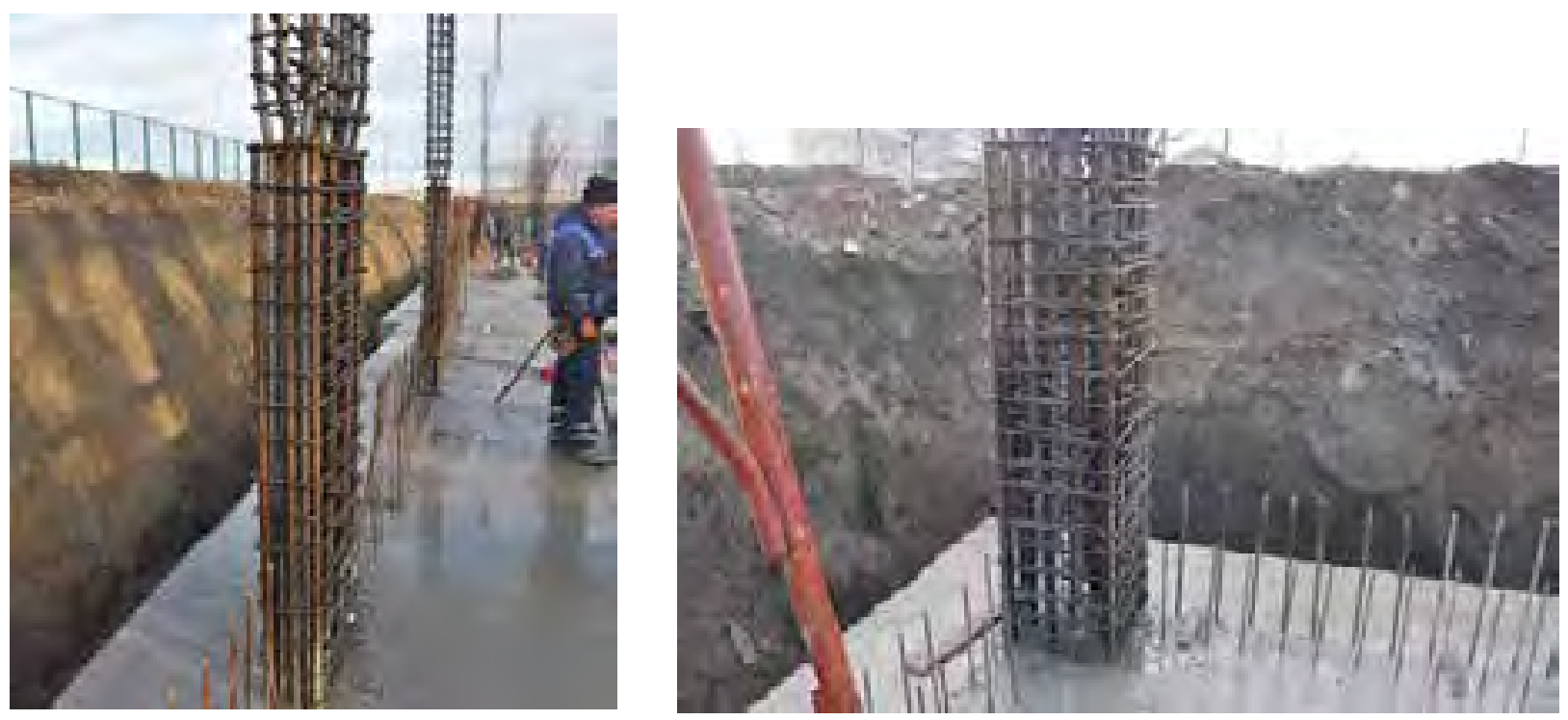

Fig. 35. Problems with clear space between both longitudinal and transverse reinforcement in lapping length of longitudinal bars (the structure was designed according to Eurocodes) 

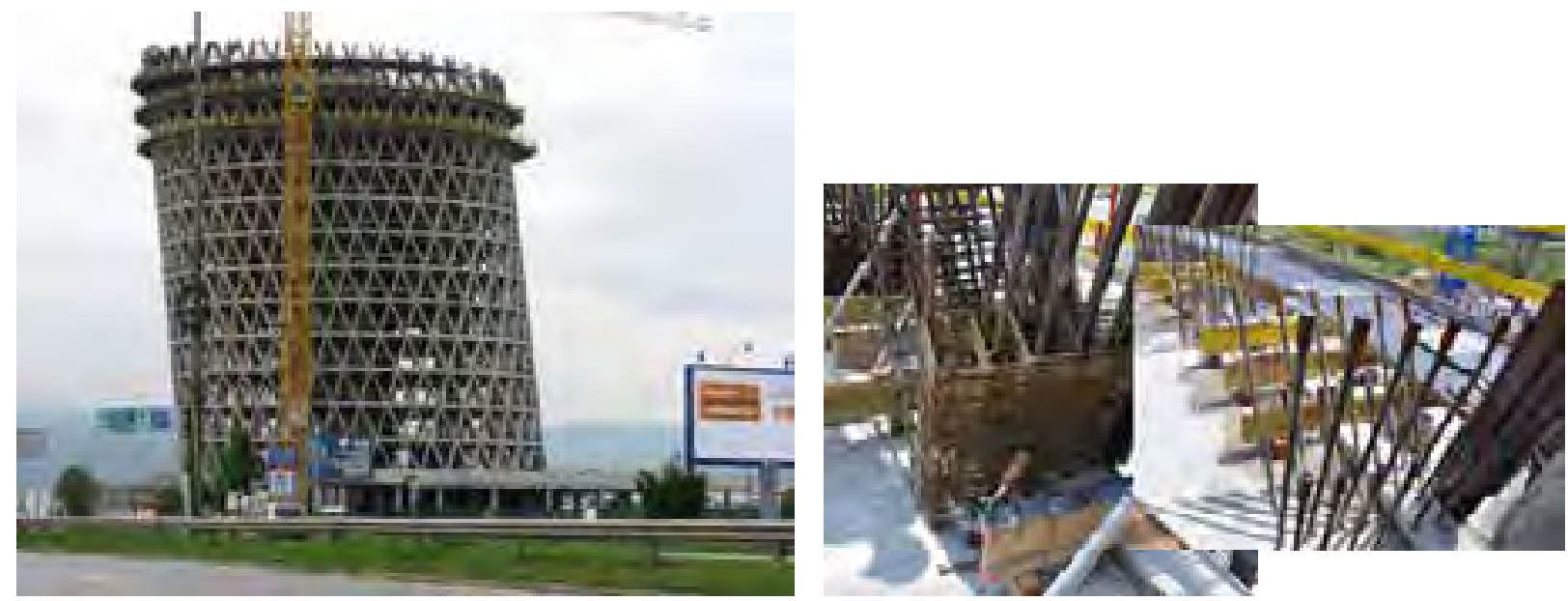

Fig. 36. Application of splicing devices for longitudinal bars in a RC building designed and detailed according to Eurocodes

\section{CONCLUSIONS}

On the basis of the study presented herein the following conclusions could be drawn:

Eurocode 8 is a code which is based on advanced theoretical background following the latest developments in the research on seismic design of buildings;

- It is necessary to ensure that structural engineers correctly implement new features of Eurocode 8 such as capacity design procedure, primary and secondary elements concept, new types of structural elements as large lightly reinforced walls, local ductility requirements for the different RC elements, etc.;

- It is expected that Eurocode 8 will ensure more stable and reliable seismic behaviour of buildings compared to old Bulgarian seismic code;

- It is possible that building structures which are designed by the Eurocodes will be slightly more expensive than those designed according to old Bulgarian seismic code;

- It is supposed that the major part of the existing buildings in Bulgaria fail to meet the strict requirements of Eurocode 8 and special attention should be made during their retrofit and reconstruction;

- There are some problems in the Bulgarian National Annexes and in the Eurocode 8 itself that should be solved.

\section{REFERENCES}

[1] Elghazouli, A., (Editor), Seismic Design of Buildings to Eurocode 8, Spoon Press, 2009;

[2] Fardis, M., at al, Designers Guide to EN 1998-1 and EN 1998-5. Eurocode 8: Design of Structures for Earthquake Resistance, Tomas Telford, 2005; [Fardis];

[3] Moehle, J., Seismic Design of Reinforced Concrete Buildings, McGrawHill, 2014

[4] Paulay, T., Priestley, M.J.N., Seismic Design of Reinforced Concrete and Masonry Buildings, John Wiley \& sons, Inc, 1992

[5] P. Bisch, E. Carvalho, H. Degee, P. Fajfar, M. Fardis, P. Franchin, M. Kreslin, A. Pecker, P. Pinto, A. Plumier, H. Somja, G. Tsionis, Eurocode 8: Seismic Design of Buildings.Worked examples, Lisbon, 2011;

[6] Milev, J., Seismic Design of Reinforced Concrete Structures, KIIP Sofia, 2012 (in Bulgarian) 


\section{PROBLEMS AND THEIR SOLUTIONS IN PRACTICAL APPLICATION OF EUROCODES IN SEISMIC DESIGN OF RC STRUCTURES}

\section{Jordan Milev}

The main purpose of the paper is to present practical application of Eurocodes in the field of RC structures design. The selected examples represent the main problems in practical application of Eurocodes for seismic analysis and design of RC Structures in Bulgarian construction practice. The analysis is focused on some structural and economic problems as well as on some contradictions in Eurocode 8 itself. Special attention is paid to the practical solution of the following problems: recognition of torsionally flexible systems, stiffness reduction of RC elements for linear analysis dimensions and detailing of confined boundary areas of shear walls, detailing of wall structures, etc. Those problems appear during the practical design of some buildings in Bulgaria. Several proposals for solving some problems defined in the paper are presented through some practical examples. Some conclusions are made for further application of Eurocode 8 in the design and construction practice. The importance of some rules and procedures in Eurocode 8 is supported by the examples of damaged RC members during the past earthquakes. The problems of Eurocode 8 and their solutions are illustrated through the experience of Bulgarian construction practice.

Key words: seismic design, Eurocode 8, reinforced concrete structures, wall structure, frame structure, local ductility, detailing rules

\section{PROBLEMI I NJIHOVA REŠENJA U PRAKTIČNOJ PRIMENI EVORKODOVA ZA PROJEKTOVANJE AB KONSTRUKCIJA}

\section{Jordan Milev}

Primarni cilj ovog rada je prikaz i analiza praktične primene Evrokodova u projektovanju armiranobetonskoih (AB) konstrukcija. Odabrani primeri ilustuju glavne probleme u praktičnoj primeni Evrokodova za seizmičku analizu i projektovanje $A B$ konstrukcija u građevinskoj praksi Bugarske. Naglasak analize je usmeren na konstrukcijske i ekonomske probleme, kao i na neke kontradiktornosti koje postoje u Evrokodu 8 (EN 1998). Posebna pažnja posvećena je praktičnim rešenjima sledećih praktičnih problema: prepoznavanje torziono fleksibilnih sistema; smanjenje krutosti $A B$ elemenata za linarnu analizu, dimenzionisanje i oblikovanje detalja utegnutih graničnih oblasti smičućih zidova; oblikovanje detalja nosećih zidova i dr. Ovi problemi se javljaju tokom praktičnog projektovanja nekih zgrada u Bugarskoj. Nekoliko predloga za rešavanje problema analiziranih u radu su predstavljeni preko praktičnih primera. Za dalju primenu Evrokoda 8 pri projektovanju i građenju formulisani su odgovarajući zaključci. Značaj pojedinih pravila i procedura u Evrokodu 8 su propraćeni primerima $A B$ elemenata oštećenih tokom prethodnih zamljotresa. Problemi vezani za Evrokod 8 i njihovo rešavanje su ilustrovani primerima i iskustvima iz praktične primene u Bugarskoj.

Ključne reči: aseizmičko projektovanje, Evrokod 8 (EN 1998), armiranobetonske konstrukcije, noseći zidovi, okvirne konstrukcije, lokalna duktilnost, pravila oblikovanja detalja 